\title{
Illiberal Constitutionalism: The Case of Hungary and Poland
}

\author{
Tímea Drinóczi ${ }^{\star}(1)$ and Agnieszka Bień-Kacała ${ }^{\star *(1)}$
}

(Received 10 March 2018; accepted 16 July 2018)

\begin{abstract}
This Article argues that, as far as Hungary and Poland are concerned, the use of term "illiberal constitutionalism" is justified. It also claims that, without denying that other states could also be considered illiberal democracies, Hungary and Poland display unique and distinctive features. These features include populist politics, which lead to the relativization of the rule of law and democracy principles, and human rights protection, which captured the constitution and constitutionalism by constitutionalizing populist nationalism, constitutional identity, and created new patrionalism and clientelism. All these features are supported by the ideological indoctrination of political constitutionalism. In the course of this process, formal and informal constitutional amendments are used, and a formal sense of constitutional democracy is maintained. Overturning these illiberal democracies by constitutional and legal means, at this time, seems doubtful, if not impossible.
\end{abstract}

Keywords: Illiberal constitutionalism; rule of law; democracy; Hungary; Poland

\section{A. Introduction}

Hungary has experienced democratic backsliding since 2010, and Poland has experienced it since 2015, despite almost 30 years of democratic development. ${ }^{1}$ Despite the fact that in the vast majority of the literature the term "illiberal constitutionalism" is not generally accepted, we claim that in

\footnotetext{
*Tímea Drinóczi, Full Professor at the University of Pécs, Hungary, drinoczi.timea@ajk.pte.hu. The research was supported by the National Science Centre, Poland, 2018/29/B/HS5/00232, "Illiberal constitutionalism in Poland and Hungary."

${ }^{* *}$ Agnieszka Bień-Kacała, Prof UK, dr hab at Nicolaus Copernicus University, Toruń, Poland, ORCID 0000-0002-95593130, abien@umk.pl. The research was supported by the National Science Centre, Poland, 2018/29/B/HS5/00232, "Illiberal constitutionalism in Poland and Hungary."

${ }^{1}$ See, e.g., Andras Jakab \& Pal Sonnevend, Continuity with Deficiencies: The New Basic Law of Hungary, 9 EUR. ConsT. L. REv. 102 (2013); Timea Drinóczi, Constitutional Dialogue and Legislation on Parliamentary Election in Hungary - 2010-2014, 4 Osteuropa Recht 452 (2014); Timea Drinóczi, Constitutional Politics in Contemporary Hungary, 1 VIENNA J. INT'L CONST. L. 63 (2016); Renata Uitz, Can you tell when an illiberal democracy is in the making?, 13 INT'L J. ConsT. L. 279 (2015); Wojciech Sadurski, How Democracy Dies (in Poland): A Case Study of Anti-Constitutional Populist Backsliding, SYDNEY LAW SCHOOL Legal Studies Research Paper No. 18/01 (2018); Urszula Jaremba, The Rule of the Majority vs the Rule of Law: How Poland Has Become the New Enfant Terrible of the European Union, 7 TIJDSCHRIFT VOOR CONSTITUTIONEEL ReCHT 262 (2016); Miroslaw Wyrzykowski, Antigone in Warsaw, in Human Rights IN CONTEMPORARY World 370 (Marek Zubik ed., 2017); Arkadiusz Radwan, Chess-Boxing Around the Rule of Law - Polish Constitutionalism at Trial, 3 PALESTRA 7 (2016); Ewa Łętowska \& Aneta Wiewiórowska-Domagalska, A 'good' change in the Polish Constitutional Tribunal?, 1 OSTEUROPA RECHT 79 (2016); Ewa Łętowska, The current dismantling of the rule of law in Poland (June 5, 2018), https://ruleoflaw.pl/the-currentdismantling-of-the-rule-of-law-in-poland/; Marcin Matczak, Poland: From Paradigm to Pariah? Polish Constitutional crisis - facts and interpretations (June 5, 2018), =https://papers.ssrn.com/sol3/papers.cfm?abstract_id=3138541; Agnieszka Bień-Kacała, Polish Constitutional Tribunal: a systemic reform or a hasty political change, 25 DPCE ONLINE 153 (2017); Joanna Fomina \& Jacek Kucharczyk, The Specter Haunting Europe: Populism and Protest in Poland, 27 J. Democracy 58 (2016); MatgorZata Szuleka et al., Helsinki Foundation for Human Rights, The Constitutional Crisis in Poland $2015-2016$ (Joanna Smętek trans., 2016), http://www.hfhr.pl/wp-content/uploads/2016/09/HFHR_The-constitutional-crisis-in-Poland-2015-2016.pdf.

(C) The Author(s) 2019. Published by Cambridge University Press on behalf of the German Law Journal. This is an Open Access article, distributed under the terms of the Creative Commons Attribution-NonCommercial licence (http://creativecommons.org/licenses/by-nc/4.0/) which permits unrestricted re-use, distribution, and reproduction in any medium, provided the original work is properly cited.
} 
Poland and in Hungary, there is an established illiberal constitutionalism. This seems to be stable, and in a short or even mid-term, its re-transformation does not seem plausible through legal means.

Therefore, in this Article, we discuss how constitutional changes can be conceptualized in the field of constitutional law by using the terms "illiberal democracy" and "constitutionalism." In our view, a populist political majority lacking self-restraint can develop an illiberal democracy, and transform a liberal constitutionalism to an illiberal one, by capturing the constitution and constitutionalism with legal means such as formal and informal constitutional change and packing and paralyzing the constitutional court. Illiberal constitutional democracy and illiberal constitutionalism are built in states that have already experienced liberal constitutionalism, and are supported by the misunderstood concept of political constitutionalism, relying heavily on the emotional components of national identity. We conceive of illiberal constitutionalism as a particular phase in the process of democratic decay or the backsliding from liberal constitutionalism towards an authoritarian regime. Law-making and adjudication in Hungary and Poland are still bound by European Union law, principles, and case law which flows into their legal systems through EU clauses or constitutional provisions.

Therefore, we, based on qualitative and quantitative arguments, argue that in the continuum from liberal democracy toward an authoritarian regime, these two states must have already passed the midway but still have not reached the far end signaled by authoritarianism. ${ }^{2}$ Illiberal constitutionalism is not the opposite of liberal constitutionalism, but instead a state in which the political power relativizes the rule of law, democracy, and human rights in politically sensitive cases; constitutionalizes populist nationalism; and takes advantage of identity politics, new patrimonialism, clientelism, and state-controlled corruption. This relativization technique has been increasingly, but only until it reaches the tolerance-threshold of either the population or the EU-for example, until it feels that transformative reforms can be made while still remaining politically unpunished.

These more political than legal considerations and the everyday application of the EU law, if nothing else, could be seen as a kind of constraint on the public power, which would also mean that the requirement of having constitutionalism, even if only its "thin form" is satisfied. Consequently, constitutional democracy, which we see as an embodiment of (liberal) constitutionalism and democracy, still exists, but its formal implementation outweighs its substantial realization. That, in turn, serves the fulfilment of the populist agenda and further consolidates the new regime of patrimonialism and clientelism. This creates a loop and escape from which, that is, the undoing of this transformation, does not seem plausible. We also argue that these are pieces of the puzzle 3 that constitutes the illiberal democracy and constitutionalism.

Within the scope of our Article, we do not analyze, but are aware of, the non-legal prerequisites for a successful transformation to an illiberal system. The first of these prerequisites is the fact that Hungary and Poland were subject to the third wave of the democratization process in 1989 and 1990, respectively. The second is the political and economic crises that have led to the strengthening of the current political majority. As a consequence of using populist rhetoric jointly with resentment politics, the majority in each country has firm political support. As a third component, the clear lack of political self-restraint should be mentioned. Last but not least, the people are either unable or

\footnotetext{
${ }^{2}$ See also Andras Bozóki \& Daniel Hegedüs, An externally constrained hybrid regime: Hungary in the European Union, 25 Democratization 1173 (2018). The authors do not treat Hungary and Poland together because they are in a different state of development. But see, e.g., Gabor Attila Tóth, Authoritarianism, in Max Planck Encyclopedia of Comparative Constitutional LaW (2017).

${ }^{3}$ Kim Lane Scheppele is right when she calls Hungary a Frankenstate, in which abusive comparative law is used to undermine the constitutional system. We would, however, rather say that it is, along with abusive constitutionalism, not a regime characteristic but a tool or a mechanism with which a certain transformation can be achieved. Kim Lane Scheppele, The Rule of Law and the Frankenstate: Why Governance Checklists Do Not Work, 26 Governance 559 (2013); David Landau, Abusive Constitutionalism, 47 U.C. DAVIS L. REV. 189 (2013).
} 
unwilling to form a strong and capable civil society, to raise their collective voice against extreme views, or to resist an aggressive and clearly misleading political campaign. ${ }^{4}$ On their own, ${ }^{5}$ these factors ${ }^{6}$ do not explain our claim that Hungary and Poland have emerged as unique illiberal democracies from those countries experiencing democratic decay. If we view them together with the above-mentioned pieces of the puzzle, however, we can see how an illiberal democracy is made.

The Article is structured as follows. In Section B we explain why both states are considered together notwithstanding numerous differences and provide for an account of their uniqueness among states experiencing democratic decay and a more detailed description of facts about both countries paths towards illiberal systems. Section $\mathrm{C}$ makes the case that both Poland and Hungary can be called illiberal systems, which are still constitutional democracies, but only in a formal sense. Section D enumerates the components, or pieces of the puzzle, that comprise an illiberal democracy. In Section E we set out some exits strategies for retransformation and argue that this does not seem to be feasible. We summarize our findings briefly and set out our conclusions in Section F.

\section{B. "Pole and Hungarian-two brothers ...."7 \\ I. Why Hungary and Poland: Differences Do Not Matter When Building Illiberal Constitutionalism}

One may ask why we consider Hungary and Poland together for this Article, especially when there are well-known differences, captured recently by, for instance, Wojciech Sadurski, ${ }^{8}$ András Bozóki, and Dániel Hegedüs. ${ }^{9}$ Indeed, the most significant differences between the Hungarian and Polish constitutional developments of the last couple of years are the following: Hungary has a new illiberal constitution; Poland does not, but the constitutional system being created seems to be supported by the population. The opposition is weak in Hungary, but still strong in Poland. The influence of oligarchs is much stronger in Hungary- "mafia state." 10 The attitude towards

\footnotetext{
${ }^{4}$ Consider, for example, the Hungarian billboard campaign on the migration threat in 2015 and the subsequent referendum on the EU quota decision in 2016. See infra notes 113 and 114.

${ }^{5}$ For the non-legal reasons for the emergence of illiberalism in Hungary and Poland, see Timea Drinóczi \& Agnieszka Bień-Kacała, Extra-legal particularities and illiberal constitutionalism: The case of Hungary and Poland, 4 ACTA IURIDICA (2018).

${ }^{6}$ See, e.g., Paul Blokker, New Democracies in Crisis? (2015); Bojan Bugarić, A Crisis of Constitutional Democracy in Post-Communist Europe: "Lands In-Between” Democracy and Authoritarianism, 13 INT'L J. ConsT. L. 219 (2015); Jacques Ruprik, The Specter Haunting Europe: Surging Illiberalism in the East, 27 J. DemOCRACY 77 (2016); Alina Rocha Menocal et al., Hybrid regimes and the challenge of deepening and sustaining democracy in developing countries, 15 S. AFR. J. INT'L AfF. 29 (2008).

${ }^{7}$ The first line of a popular bilingual saying about the traditional kinship, brotherhood, and camaraderie between the Polish and Hungarian peoples:
}

Polak, Wegier-dwa bratanki, $i$ do szabli, $i$ do szklanki, oba zuchy, oba żwawi, niech im Pan Bóg błogosławi.

Lengyel, magyar-két jó barát, Együtt harcol s issza borát, Vitéz s bátor mindkettöje, Áldás szálljon mindkettőre.

Pole and Hungarian - two brothers, good for saber and for glass. Both courageous, both lively, May God bless them.

${ }^{8}$ Sadurski, supra note 1 , at 4-8.

${ }^{9}$ Bozóki \& Hegedűs, supra note 2 .

${ }^{10}$ Bálint Magyar, Post-Communist Mafia State: The Case of Hungary (2016). 
Russia differs-Hungary supports Russia, Poland does not. Political influence of the Catholic Church is stronger in Poland. Hungary has a rather pragmatic relation with the EU, while it is more emotional for Poland. In our view, however, these differences seem to be irrelevant because they do not affect the continuous support of the voters or the transformative nature of the illiberal changes, which seem to be a copy-paste activity in Poland. Moreover, these differences have nothing to do with the inability of the international and supranational community to reverse changes.

We claim, therefore, that as far as politicians are using similar political means to achieve the very same goal of building illiberal constitutionalism based on a strong and effective state governed by a populist leader who also governs a homogenous nation, differences stemming from current constitutional and political context do not matter. Relationships with the Church or Russia or the attitude toward the EU do not influence the ordinary citizen who is still an enthusiastic supporter of the Hungarian or Polish populist leaders, notwithstanding the controversial national politics and clear xenophobia instigated towards foreigners. This might have something to do with the fact that Polish and Hungarian voters show similar value attitudes: Majoritarian understanding of democracy; ${ }^{11}$ stong desire for stability, which is the reason why they are willing to trade of liberal and democratic values; tendency towards conservativism and authoritarianism; prioritizing hierarchy as value, as opposed to egalitarianism, intellectual and affective autonomy, and mastery. ${ }^{12}$ Therefore, above-mentioned differences in constitutional and political contexts sare just the consequence, but not the root, of illiberal state building. The transformative power of these changes may be found in the historical and emotional trajectory of the people, as it is still the people who tolerate, accept, and even support the changes and populist politics. It seems that people want, or at least do not substantially oppose, the new system developing in Hungary and Poland.

From a historical perspective, Hungarians and Poles share similar experiences, especially after the Second World War. Despite differences in constitutional history, historical particularities and emotional trajectory of both Hungarians and Poles seem to create a receptiveness to populism and call for a stronger autocratic leader. Narrative psychological studies ${ }^{13}$ support the assertion that the Hungarian historical trajectory - collective victimhood caused primarily by the Trianon peace treaty in $1918,{ }^{14}$ citizens having been abandoned in their disappointment by all regimes

\footnotetext{
${ }^{11} \mathrm{See}$ Jan EichHorn et al., Open Society European Policy Institute, How European Publics and Policy Actors VAlues An Open SOCIETY: Key Insights ACross Countries (2019), http://voicesonvalues.dpart.org/images/finalreports/ OSI-019-18-Key-Insights_v5.pdf. The reports on Hungary (by Bulcsú Hunyadi, Csaba Molnár, Veszna Wessenauer), Poland (by Filip Pazderski), Italy, Germany, and France are available at http://voicesonvalues.dpart.org/. It is of interest that Italians, who dealt with a populist governmental crisis in August 2019, share similar value attitudes toward open society values as Hungarians and Poles. Additionally, Zygmunt Bauman opines that it is rather the pluralism of moral rules that put the people into the feelings and fears of uncertainty and ambivalence. Thus, pluralism has brought chaos among moral values; the world full of almost non-limited freedom and overwhelming responsibility for peoples' own choices created the crisis of morality. Therefore, a strong need of stable, solid, and firm values provided by authority arises. ZYGMUNT BAUMAN, ETYKA PONOWOCZESNA [The Late Modern Ethics] (2012).

${ }^{12}$ Shalom H. Schwartz \& Arat Bardi, Influences of Adaptation to Communist Rule on Value Priorities in Eastern Europe, 18 Pol. PsYCHOL. 398 (1997).

${ }^{13}$ Narrative psychology provides a dynamic approach to understanding human identity and the process of making sense of our ever-changing world. See generally, Ulrike Popp-Baier, Narrative Psychology, in ENCYCLOPEDIA OF SCIENCES AND Religions (A.L.C. Runehov \& L. Oviedo, eds., 2013); Éva FülöP ET Al., EMOtional Elaboration of Collective Traumas IN Historical NARRATives (2014) http://real.mtak.hu/20201/3/emotional_elaboration_of_collective_traumas. pdf; Adam Jefferys, What is Narrative Psychology?, PEN \& THE PAD (Mar. 10, 2017), https://penandthepad.com/narrativepsychology-3393.html; Janos László, Narratív pszichológia, 28 PszICHOLÓGIA (2008), http://real.mtak.hu/2385/1/ 49413_ZJ1.pdf; Michael Murray, Narrative psychology and narrative analysis, in QUALITATIVE RESEARCH IN PSYCHOLOGY: Expanding Perspectives in Methodology and Design 95 (Paul M. Camic, et al. eds., 2003), https://www. researchgate.net/publication/274889276_Chapter_6_Narrative_psychology_and_narrative_analysis.

${ }^{14}$ The Treaty of Trianon was the peace agreement of 1920 to formally end World War I between most of the Allies of World War I and the Kingdom of Hungary, which was at that time, a "monarchy without a monarch." Around two-thirds of the
} 
throughout Hungarian history — ${ }^{15}$ is not a favorable ground to build an emotionally stable identity upon, ${ }^{16}$ and that the unettled and vulnerable identity longs for stability, which they find in an autocratic leader from the right-wing. ${ }^{17}$

In Poland, the narrative psychology is not as advanced as in Hungary, but our assertion concerning the Polish emotional trajectory seems to be supported by historians, ${ }^{18}$ societal psychologists, ${ }^{19}$ sociologists, and philosophers. ${ }^{20}$ Poles are characterized as a traumatized nation because of the loss of statehood and independence, a nation that has a controversial attitude towards liberty, and a nation with has a firm Catholic belief, resulting in a lack of pluralism. Another strong feeling is messianism combined with megalomania. Parochialism and a folwark-like ${ }^{21}$ societal structure are also existing phenomena. ${ }^{22}$ As a result, Poles organize themselves by creating a hierarchy with a strong leader on the top, and thus, a democratic method of decision making is almost impossible.

Schwartz and Bardi's findings from 1997 on the value priorities in the region after the communist rule seem to be supported by the the Value research results published in 2019. They concluded that the value profile common in Eastern European countries, which lacks the commitment to egalitariansim and autonomy values, is ill-suited for the development of democracy. ${ }^{23}$

Beyond having the same king and being bound by the personal union in the Middle Ages, ${ }^{24}$ the socialist Hungary and Poland, under the influence zone of the Soviet Union, were forced to adopt a communist constitution which introduced the socialist model of state and legal systems. In the late 1980's, Hungary and Poland underwent similar transition processes from socialism to democracy. By using different approaches towards constitution-making, they created new constitutional regimes, ${ }^{25}$ which were based on the rule of law, democracy, and human rights. ${ }^{26}$ Hungary and Poland created liberal constitutionalism-the need to constrain

territory of the country was allocated to neighboring countries, along with its population. One-third of the Hungarians were left outside of post-Trianon Hungary.

${ }^{15}$ György Spiró, Két középkelet-európai mentalitás az államiság szempontjából, 2000 IRODALMI És TÁRSADALMI HAVI LAP 6 (2007); Fülöp et al., supra note 13, at 7, 19.

${ }^{16}$ FÜlÖP ET AL., supra note 13, at 11.

${ }^{17}$ Hajdu Tamara, A magyar identitás szabadságharcos - interjú Szabó Zsolttal, az ELTE Szociálpszichológia tanszékének adjunktusával, Mindset PsZichologia (Nov. 18, 2017), http://mindset.co.hu/a-magyar-identitas-szabadsagharcos-interjuszabo-zsolttal-az-elte-szocialpszichologia-tanszekenek-adjunktusaval/.

${ }^{18}$ Anna Tarnowska, The Sovereignty Issue in the Public Discussion in the Era of the Polish 3rd May Constitution (1788-1792), in Reconsidering Constitutional Formation I National Sovereignty 215 (Ulrike Müßig ed., 2016); WojCiech WrZesiński, CHARAKTER NAROdOWY POLAKÓW. Z ROZWAŻAŃ HISTORYKa [National character of Poles. From the historian's reflections] (2004).

${ }^{19}$ Anna Zajenkowska, Polska na Kozetce. SiŁa obywatelskiej Refleksyjności [Poland on the couch. The power of

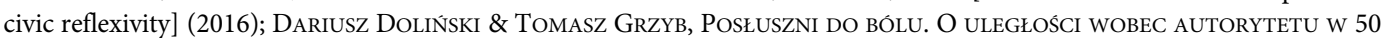
LAT PO EKSPERYMENCIE Milgrama, [Painfully obedient. On the submission to authority 50 years after Milgram's experiment] (2017).

${ }^{20}$ Adam Leszczyński, No dno po prostu jest Polska. Dlaczego Polacy tak bardzo nie lubią swojego KRaju I INNYCH POLAKÓW [Poland hit the rock bottom. Why Poles do not like their country and other Poles] (2017); PIOTR Augustyniak, Homo Polacus. Eseje o POlskiej duszy [Homo Polacus. Essays about Polish soul] (2015).

${ }^{21}$ A primarily serfdom-based farm and agricultural enterprise, Folwarks originated as land belonging to a feudal lord and not rented out to peasants but worked by his own hired labor. The peasants toiled on the lots they rented from the lord, but in addition were obliged to provide complimentary labor for the lord on his Folwark.

${ }^{22}$ Eliza Michalik \& Jacek Santorski, Polska na kozetce [Poland on the couch] (2016).

${ }^{23}$ Supra note 11; Schwartz \& Bardi, supra note 12, at 407-08.

${ }^{24}$ The personal union between the Kingdom of Hungary and the Kingdom of Poland was achieved twice: In 1370-1382 under Louis I of Hungary and in 1440-1444 under Vladislaus III of Poland.

${ }^{25}$ Poland adopted the so-called Small (Interim) Constitution in 1992 and started to work on the new one that was finally approved in 1997. Hungary, mainly due to the features of the transition, decided not to adopt a new constitution but almost entirely changed the socialist one during a series of constitutional amendments.

${ }^{26}$ Both states joined the Council of Europe-Hungary in 1990, Poland in 1991-and ratified the European Convention of Human Rights. Hungary joined in 1992, and the ECHR entered into force in Hungary in 1993. Poland joined in 1993, and the ECHR entered into force in 1993. 
public power and defend human rights through the idea of the rule of law as prescribed in a written constitution - and democracy-rule by the people, usually but not exclusively thorugh elected representatives who, to a certain extent and without disregarding minority opinions, represents the view of the majority-as a package, as opposed to their gradual development in the more Western side of the world. ${ }^{27}$ Therefore, in the newly established constitutional system, which we call constitutional democracy, liberal constitutionalism, and democracy were not conflicting values but rather were meant to complement each other.

Nevertheless, as Thomas Humphrey concluded in 2008, without a rigourous rule of law or commitment to constitutionalism defended and - as a matter of fact-enriched by constitutional courts, the democratic transition might not have been succesful, because without the rule of law, liberal and democratic rights are not safe, and the equal dignity of all citizens are endangered. ${ }^{28}$ The transformation process was facilitated and actively assisted by the constitutional courts. Both the Hungarian Constitutional Court ("CC") and the Polish Constitutional Tribunal ("CT") embraced an activist approach towards constitutional interpretation, which was required by both the fact and fragility of the transition, as well as some vague constitutional provisions. Both states joined the European Union in 2004, which meant that they acknowledged mutual interests and values shared by the Member States and adapted their legal systems to the accession.

Hungary and Poland emerged from a troubled history, which left its mark on the emotional trajectory of their populations. This state of emotions, with strong resentment beneath ${ }^{29}$ could easily be intensified and exploited by today's populist leaders. ${ }^{30}$ Moreover, those emotions have been reflected in the way the leaders organize their political environment: They are the reason why the people are receptive. The emotions also explain the fact that Hungary and Poland are the most renegade members of the European Union, and why the EU seems not entirely successful in adequately addressing populist and illiberal leaders, notwithstanding Article 7 procedure.

In our view, the unfortunate coincidence and synergy of these factors make Hungary and Poland, notwithstanding the differences, comparable, and forces them together to the category of illiberal constitutionalism.

\section{The Uniqueness of the Backsliding of Hungary and Poland: Illiberal Within States of Democratic Decay}

The historical particularities and emotional trajectory that pushed Hungary and Poland to the arms of populism and illiberalism are not the only reasons why we argue that the Hungarian and Polish cases are unique. Below, we describe the factors that, in our view, amplified the already existing national emotions.

\footnotetext{
${ }^{27}$ Classic constitutionalism was born before democracy in its modern form with universal suffrage taking root.

${ }^{28}$ Thomas Humphrey, Democracy and the Rule of Law: Founding Liberal Democracy in Post-Communist Europe, 2 CoLUM. J. E. EUR. L. 94, 124 (2008).

${ }^{29}$ Tomasz Tadeusz Koncewicz, Unconstitutional capture and constitutional recapture. Of the rule of law, separation of powers and judicial promises (Jean Monnet Ctr. for Int'l \& Regional Econ. L. \& Just., Working Paper 3/17).

${ }^{30}$ For the appearance of illiberal democracy in political communication, see Viktor Orbán, Prime Minister of Hungary, Speech at the 25th Bálványos Summer Free University and Student Camp (July 26, 2014), http://www.kormany.hu/en/theprime-minister/the-prime-minister-s-speeches/prime-minister-viktor-orban-s-speech-at-the-25th-balvanyos-summer-freeuniversity-and-student-camp. See also Kaczyński's slogan: “[T]here will be Budapest in Warsaw” in 2011 when PiS lost the parliamentary election, TVN24, "Przyjdzie dzień, że $w$ Warszawie będzie Budapeszt” (Oct. 9, 2011), http://www.tvn24.pl/ wiadomosci-z-kraju,3/przyjdzie-dzien-ze-w-warszawie-bedzie-budapeszt,186922.html. After 2015, when PiS won elections, it was made clear that the slogan was meant to become a philosophy, Program PIS 2014, LAW \& JUSTICE 7, 12 (Oct. 31 , 2017), http://pis.org.pl/dokumenty.
} 


\section{National Context}

Jan-Werner Müller ${ }^{31}$ observes the worldwide wave of populism and argues that populism cannot be perceived as an authentic part of modern democratic politics or as a kind of pathology caused by irrational citizens, but is a permanent shadow over representative politics. We claim, however, that the Hungarian and Polish cases are unique because of the transformative power of populism. Populist parties, in both states, won the general election after previous episodes of unsuccessful government-Hungary in 2006-2010 and Poland in 2005-2007-with a constitutional majority in Hungary in 2010, 2014, and 2018, and an absolute majority in Poland in 2015.

Just after creating the new government, populist leaders Viktor Orbán-prime minister, formal authority - in Hungary and Jarosław Kaczyński—president of the party, informal authority-in Poland started to transform the existing liberal democracies. Because of the different general election results, these leaders used different transformational means. The Hungarian way was more formal, based on constitutional measures such as adoption and amendments of the constitution that have been abusive. Poland uses informal tools of transformation, breaching and disregarding constitutional provisions, especially in connection to the CT and judiciary. In effect, the Hungarian system is based on an illiberal constitution-2011 Fundamental Law-whereas the Polish system is based on the delegitimization of the still-binding 1997 Constitution. This leads undeniably to a creation of a new illiberal constitutional system.

In the case of Hungary and Poland, an illiberal constitution should be understood more narrowly than a populist constitution. ${ }^{32}$ As far as populist constitutionalism is concerned, we would not consider it a legal concept but mainly a sociological phenomenon, and as such it is a sociological characteristic of the constitutional system and forms the sociological basis for either an illiberal or an authoritarian system. The populist attitude of rulers is a tool to gain popular support for them to govern. Nevertheless, they still need to transform the system through legal measures, such as adopting a new constitution or introducing retrograde abusive amendments and clearly unconstitutional legislation. ${ }^{33}$ In both states, the political majority first captured independent institutions of checks and balances by packing the constitutional courts, changing the appointment process of constitutional court judges in Hungary or their decision-making process in Poland, and reforming the judicial system and rules regarding the prosecutor general. As a result, the constitutional courts in particular have become the servants of the ruling parties and leaders, and they have started to justify transformative political and legal actions.

The political decision-makers have not left intact other democratic institutions either. Lately, they introduced new laws and changed others in the field of, for example, elections, ombudsman, judiciary and court systems, and civil society. They provided less and less protection to the individuals by restricting their freedoms of assembly, expression, the press, and other means of social communication.

\section{European and Worldwide Context}

In both states, in one way or another, core institutions of human rights and civil society were adjusted to the populist party's needs. These events have met strong, yet unsuccessful, reactions from international-Venice Commission and UN-and supranational-EU, Article 7 procedureorganizations. This transformative effect and the seemingly apparent inability of the international and supranational community to directly address illiberal changes support our claim that the Hungarian and Polish cases are unique.

\footnotetext{
${ }^{31}$ Jan-Werner Müller, What is Populism? 16 (2016).

${ }^{32}$ David Landau, Populist Constitution, 85 U. CHI. L. REv. 521 (2018).

${ }^{33}$ Thus, if there exists a populist Constitution, with big "C," in the populist constitutionalism, like in Hungary, it may be developed into an illiberal Constitution and constitutionalism or authoritarian constitution and authoritarian regime depending on people's support, which is high for illiberal, and the irrevocability of an autocratic party or leader in national electionauthoritarian regime.
} 
The backsliding from liberal constitutionalism we witnessed in Hungary and Poland ${ }^{34}$ seemed to be a European - more precisely Hungarian and Polish - phenomenon, and not yet a worldwide phenomenon. As Levitsky and Way explained in 2015, empirical records suggest that there is little to no evidence of a worldwide democratic recession. ${ }^{35}$ In practice, they identified stability rather than a decline, mainly due to the counterbalancing effect of other states; while Hungary and Poland have been in decline, others such as Colombia, and until recently, Brazil were able to strengthen their democracy. ${ }^{36}$ That said, Freedom House observed more revearsals than gains between 2006 and $2016 .{ }^{37}$ Whichever is the case, systems have been changing from their original state, which is not necesserily liberal constitutionalism, ${ }^{38}$ to something new that is often perceived as worse than before. Democratic decay, however, appears to be affecting liberal democracies ${ }^{39}$ who face major economic and financial crises and are struggling with migration challenges and the terror threat. Yet, even if we see the results of the undeniable populist influence, there are remarkable differences between states in democratic decay.

Having said that, we assume, at this point, that there are several factors still to be explored in greater detail which make the democratic decay in Hungary and Poland unique. Compare, for example, the unpopularity of Brazilian politicians and the new role of the judiciary in fighting against corruption, ${ }^{40}$ with the continuing popularity of the Fidesz Party in Hungary or the popular support the PiS receives in Poland. Further, while in Hungary and Poland, the judiciary, including the constitutional courts, has already been compromised, the United States continues to enjoy an uncompromised judicial system. The different historical roots of constitutional development in these states, the more-or-less unified commitment towards the same constitutional principles in Europe, and the different attitudes to military coups d'état should also be taken into account. In addition, this powerful and concentrated transformation of the system that occurred in Hungary and Poland has not been observed in other countries where populist parties won general election, such as Czech Republic, Slovakia, Austria and Italy. Furthermore, the way the illiberal transformation has been accomplished in Hungary and Poland may be seen as special, with its origins in the third wave of the democratization process.

The third wave of the democratization process led to three results. The first was a constitutional democracy, which still has not shown any sign of regression. ${ }^{41}$ Second, it resulted in an authoritarian reconsolidation, which, according to Steven Levitsky and Lucan Way, is not to be viewed as a democratic rollback. ${ }^{42}$ Third, democracy in some other states reverted to a more or less authoritarian form, as Alina Rocha Menocal and others observe, relying on Latin-American and African

\footnotetext{
${ }^{34}$ See The Economist, Democracy Index 2016: Revenge of the “Deplorables” 6 (2016). Hungary ranks 56, Poland 52. Hungary was continuously dropping its index score, from 7.65 in 2006 to 6.72 in 2016. Backsliding between 2006 and 2010 under the socialist and liberal government-was not as great as between 2010 with 7.53-7.21 and 2016 with 7.21-6.72. Poland's backsliding has not been continuous: It dropped back only in 2010 to 7.05 and 2016 to 6.83 . It achieved its highest score in 2014 of 7.47.

${ }^{35}$ See Steven Levitsky \& Lucan Ahmad Way, The Myth of Democratic Recession, 26 DemocracY 45 (2015).

${ }^{36} I d$.

${ }^{37}$ Arch Puddington, Breaking Down Democracy: Goals, Strategies, and Methods of Modern Authoritarians (2017), https://freedomhouse.org/sites/default/files/June2017_FH_Report_Breaking_Down_Democracy.pdf. See, for instance, the recent Brazilian crisis, which is explained in Fernando José Gonçalves Acunha \& Juliano Zaiden Benvindo, Democratic Decay in Brazil and the New Global Populism, InT'L Ass'N Const. L. Blog (June 6, 2017), https://blog-iaclaidc.org/test-3/2018/5/26/democratic-decay-in-brazil-and-the-new-global-populism.

${ }^{38}$ Venezuela degraded from competitive authoritarianism to a more increasing authoritarianism which Javier Corrales calls autocratic legalism. Javier Coralles, The Authoritarian Resurgence: The Authoritarian Legalism in Venezuela, $26 \mathrm{~J}$. DEMOCRACY 37 (2015).

${ }^{39}$ See e.g., Tom Gerald Daly, Diagnosing Democratic Decay, Comp. Const. L. Roundtable (Aug. 7, 2017), https://www. academia.edu/34052302/Diagnosing_Democratic_Decay.

${ }^{40}$ Acunha \& Benvindo, supra note 37.

${ }^{41}$ See, for example, the Baltic states, especially Estonia.

${ }^{42}$ Levitsky \& Way, supra note 35 , at 52.
} 
experiences. In our view, the authoritarian reconsolidation would not typify the Central and Eastern European ("CEE") states. The reason is that those in power in the regime from which the democratic transition emerged, the communist-socialist party, differ from those that hold power now, right-wing parties and conservatives. That said, the authoritarian form, the third result, could fit the CEE context, ${ }^{43}$ regardless of the label we attach. The reason is simple, as is stated by Menocal et al about the countries in which they are interested: The main political players, forces, and institutions do not accept democracy as "the only game in town." ${ }^{24}$ In our case, due to the constitutional and historical development of the European states, consitutionalism, ideal of democracy, and the European Union, the only game in town is the constitutional democracy or multilevel constitutionalism, which is not taken seriously enough by the Hungarian and Polish actors.

And here is where Tushnet's thesis, as explained in his work about authoritarian constitutionalism, needs to be mentioned. In authoritarian constitutionalism, liberal freedoms are protected at an intermediate level, elections are reasonably free and fair, and there is a normative commitment to constraints on public power. Against this background, Tushnet differentiates between the abusive constitutionalism of Hungary and the authoritarian constitutionalism of Singapore. He speculates that the "normative commitment to constraints on public power," which he extracted from the "description of how constitutionalism operates in Singapore, might be a truly distinguishing characteristic of authoritarian constitutionalism." ${ }^{25}$ It seems, however, that a "normative commitment to constraints on public power" is missing in Poland and Hungary. Exercise of public power remains almost unconstrained; political leaders do not respect the idea of constitutionalism. ${ }^{46}$ Nevertheless, the system they have-or are about to consolidate-must respect, to the desirable extent, the EU law, which apparently functions as an internal and implied constraint. If we consider the EU law as part of the legal systems of the Member States, any constraint on its daily application, at politically irrelevant or less relevant levels, and possible influence on the populist agenda, needs to be seen as an internal, constitutional constraint. This type of constraint only exists within the EU. Thus, based on Tushnet's position, the new systems in Hungary and Poland cannot be labelled authoritarian constitutionalism.

\section{What Is Illiberal Constitutionalism?}

Political slogans such as "an illiberal democracy is being built" ${ }^{7}$ have appeared and led to the reformation and demolition of the formerly existing Hungarian and Polish legal frameworks. ${ }^{48}$ Even if Jarosław Kaczyński did not describe his vision of the new Polish system as illiberal, he said that "there will be Budapest in Warsaw," ${ }^{9}$ expressing his willingness to follow Orbán's vision as much as he can. In order to successfully shape an illiberal state, the political leaders of Hungary and Poland created a constitutional democracy in the formal sense. They relativized the rule of

\footnotetext{
${ }^{43}$ Menocal et al., supra note 6 , at 30 .

${ }^{44}$ Menocal et al., supra note 6, at 31; see also ARMin von Bogdandy ET AL., Transformative Constitutionalism IN Latin America. The Emergence of A New Ius Commune (2017).

${ }^{45}$ Mark Tushnet, Authoritarian Constitutionalism, 100 CoRnell L. Rev. 391, 438 (2015).

${ }^{46} \mathrm{It}$ is shown in the indexes as well if one compares the rule of law commitment of Singapore with a global rank of 13 and Hong Kong with a global rank of 16 with that of Poland's global rank of 27 and Hungary's global rank of 57. WORLD JUSTICE PROJECT, Rule of LAW INDEX 2019 (2019), https://worldjusticeproject.org/sites/default/files/documents/WJP-ROLI-2019Single\%20Page\%20View-Reduced_0.pdf.

${ }^{47}$ Orbán, supra note 30.

${ }^{48}$ Fareed Zakaria, The Rise of Illiberal Democracy, 76 ForeIGN AfF. 22 (1997); FAREed ZaKaria, The FutUre OF FrEEDOM: Illiberal Democracy at Home AND Abroad (2007).

${ }^{49}$ This is what he said in 2011 when the Law and Justice Party, PiS, lost the parliamentary election, see Przyjdzie dzień, ze $w$ Warszawie będzie Budapeszt, TVN24 (Oct. 9, 2011), http://www.tvn24.pl/wiadomosci-z-kraju,3/przyjdzie-dzien-ze-wwarszawie-bedzie-budapeszt,186922.html. After 2015, when PiS won the election, it was made clear that the expression was not restricted to the election result but has become a philosophy, see PIS, LAW \& JUSTICE, supra note 30.
} 
law, democracy, and human rights; captured the constitution and constitutionalism by constitutionalizing constitutional identity; employed populist nationalism; created new patrionalism and clientelism; and controlled state-level corruption. All this appears to be supported by the ideological indoctrination of political constitutionalism. Formal and informal constitutional amendments have been used, and a formal kind of constitutional democracy has been maintained.

We have chosen to call Hungary and Poland's illiberal state "illiberal constitutional democracy." Illiberal constitutional democracy, illiberal democracy, and illiberal constitutionalism are used in this Article interchangeably, despite the fact that, as mentioned above, in scholarly literature these terms recently have not been welcome. Below, we make a case for why we see this differently.

\section{Puzzled-How to Name It: Illiberal}

Authors on the subject try to find a label that best expresses the ongoing Hungarian and Polish developments. None of them, however, argue that the term "illiberal," or even "constitutionalism," should be used. Lately, some authors have declared themselves uncertain whether it is still correct to refer to the Hungarian and Polish legal orders as "constitutionalism." Kim Lane Scheppele, Gábor Halmai, and Gábor Attila Tóth either avoid using the term or, when they do use it, call it an oxymoron. For them, neither Hungary nor Poland is a democracy or, from a strict liberal constitutionalist point of view, can be described as constitutionalism. Their main argument is that constitutionalism cannot be anything but liberal. Consequently, Hungary is described as a modern authoritarian regime. ${ }^{50}$ Others, like Mark Tushnet, Tom Gingsburg, and Aziz Z Huq, Helena Alviar, and Günter Frankenberg in their co-authored and edited books, either use other adjectives to constitutionalism like authoritarianism, study the possibility of illiberal constitutionalism, or claim that constitutionalism is feasible in the absence of liberal entitlements and democratic processes. ${ }^{51}$ Further, Paul Blokker refers to "populist constitutionalism," ${ }^{2}$ Scheppele proposes "authocratic legalism," 53 and Sadurski uses the term "constitutional breakdown" and names Polish events "anti-constitutional populist backsliding." ${ }^{54}$ Many others describe the events that led to the "backsliding" in Hungary and Poland and put them in a wider Central and Eastern European, ${ }^{55}$ European, ${ }^{56}$ or global ${ }^{57}$ context. The labelling of this phenomenon varies widely. ${ }^{58}$ References are made to "borderline authoritarianism," 59 "illiberal regimes," "grey-zone" countries, ${ }^{60}$ the "transition away from democracies," 61 "democracies in regression," 62 "competitive

\footnotetext{
${ }^{50}$ Gábor Halmai, Populism, Authoritarianism, and Constitutionalism, 20 GERMAN L.J. 296 (2019); Gábor Attila Tóth, Illiberal Rule of Law? Changing Features of Hungarian Constitutionalism, in CONSTITUTIONALISM AND THE RULE OF LAW: Bridging IdeAlism AND Realism 386 (Maurice Adams, Anne Meuwese, \& Ernst Hirsch Ballin eds., 2017).

${ }^{51}$ See Tushnet, supra note 45; Helena Alviar \& Günter Frankenberg, Authoritarian Constitutionalism (2019); Mark Tushnet, The Possibility of Illiberal Constitutionalism, 69 Fla L. Rev. 1367 (2017); Tom GIngsburg \& AzIz Z. Huq, How to Save Constitutional Democracy? (2018). Another alternative view can be seen in David S. Law, Alternatives to Liberal Constitutional Democracy, 77 MD. L. ReV. 223 (2017); Bruce P. Frohnen, Is Constitutionalism Liberal?, 33 CAmpbell L. ReV. 529 (2011); Jorge M. Farinacci-Fernós, Post-Liberal Constitutionalism, 54 TulSA L. ReV. 1 (2018).

${ }^{52}$ Paul Blokker, Populist constitutionalism, VerFBlog (May 4, 2017), https://verfassungsblog.de/populist-constitutionalism/.

${ }^{53}$ Kim Lane Scheppele, Autocratic Legalism, 85 U. CHI. L. Rev. 545 (2018).

${ }^{54}$ WojCiech Sadurski, POland's CONSTitutional Breakdown (2019).

${ }^{55}$ Bugarić, supra note 6; BLOKKER, supra note 6.

${ }^{56}$ Ruprik, supra note 6, at 137.

${ }^{57}$ Levitsky \& Way, supra note 35 , at 48 .

${ }^{58}$ Levitsky \& Way, supra note 35 , at 45 .

${ }^{59}$ Levitsky \& Way, supra note 35 , at 47.

${ }^{60}$ Larry Diamond, Facing Up to the Democratic Recession, 26 J. DEMOCRACY 142 (2015).

${ }^{61}$ Ruprik, supra note 6, at 133.

${ }^{62}$ Ruprik, supra note 6 , at 77 .
} 
authoritarianism,"63 or "authoritarian constitutionalism." ${ }^{64}$ Hungarian events have even been considered to be "counter-constitutional revolution"65 and "abusive constitutionalism," 66 although the latter label does not entirely fit the Polish case, which has been described as "anti-constitutional populist backsliding."

Müller opposes the term "illiberal" 68 and suggests instead the term "undemocratic." ${ }^{\prime \prime}$ What he describes as the problem with the term "illiberal democracy" - that it is used to justify the "undemocratic" actions of governments, such as the attack on democracy's very foundationsassembly, media and thus hindering political opposition-is indeed a problem. Unfortunately, however, these governments are not acting in an undemocratic way at all. Democratic mechanisms are used, democratic rules are observed - at least formally-and political actors and governments have legitimacy as well. If we get rid of the term "illiberalism," the observance of formal democratic rules and others that we discuss in this Article do not seem to be taken into consideration. What Müller sees as undemocratic is rather, from a legal perspective, ${ }^{70}$ unconstitutional but democratic in a formal sense. ${ }^{71}$ Constitutionality and democracy and their opposites, even though they may overlap to a certain extent, are not the same. For a legal scholar, constitutionality absorbs democracy, while it may be just the opposite for others taking a less legally oriented view.

Moreover, even if Hungary has recently been labeled partly free by the Freedom House-while Poland still retains its free status - the democratic degeneration of the system has not reached the extent of that of Turkey or Russia, the two countries commonly mentioned together with Hungary and Poland as examples of modern authoritarianism. ${ }^{72}$ It is undeniable that the systemic changes are pointing towards that direction. The political systems, especially that of Hungary, could even be called hybrid regimes, standing between democracy and authoritarianism, from a political science persepctive. ${ }^{73}$ In our view, however, when trying to understand the democratic decay in Hungary and Poland, one should not forget that sometimes the matter of degree-what different types of indexes indicate-is a matter of kind. Not to mention the fact that Hungary and Poland are still members of a regional community built on democracy, rule of law, and human rights. Insofar as regional community membership is maintaned by both parties, for example between the EU and the two states, Hungary and Poland should be considered constitutional democracies even if in a flawed, thin, or merely formal version. Exactly this is why we chose to call this phenomenon illiberal democracy or illiberal constitutionalism. The palpable oxymoron in the term intends to highlight the paradox in which Hungary, Poland, and the EU find themselves. First, the EU, which is built on certain principles, still has two Member States that keep disrespecting those very same principles. Second, it seems that both the EU and Hungary and Poland are comfortable with the regime-sustaining and legitimazing role the EU plays. ${ }^{74}$ Third, the populist leaders of

\footnotetext{
${ }^{63}$ Bugarić, supra note 6, at 223; Diamond, supra note 60, at 148.

${ }^{64}$ Tushnet, supra note 51.

${ }^{65}$ BLOKKER, supra note 6 , at 171 .

${ }^{66}$ Landau, supra note 3.

${ }^{67}$ Sadurski, supra note 1 .

${ }^{68}$ Jan-Werner Müller, The Problem With "Illiberal Democracy", Soc. EuR. (Jan. 27, 2016), https://www.socialeurope.eu/theproblem-with-illiberal-democracy.

${ }^{69} I d$. at 61 .

${ }^{70}$ What makes a constitutional law analysis difficult, however, is that what is evidently unconstitutional will not necessarily be declared unconstitutional by a constitutional court. This disagreement on the constitutionality of a law goes beyond the usual disagreements that we experience regarding court decisions. Thus, unconstitutionality may be upheld in a constitutional way. On the paradox of constitutional amendments, see Section D.I.2.

${ }^{71}$ It is thus clear that legal and the political analysis are often interwoven, but in this Article, we give more weight to the legal analysis.

${ }^{72}$ Tóth, supra note 2; PudDINGTON, supra note 37.

${ }^{73}$ Bozóki \& Hegedüs, supra note 2, at 1175.

${ }^{74}$ Functions borrowed from Bozóki \& Hegedűs, supra note 2, at 1174.
} 
Hungary and Poland act like children who try to find where the boundaries of their actions are, and keep pushing as far as they can. The uniquness of the Hungarian and Polish illiberal constitutionalism rests on these phenomena.

\section{Puzzled-How to Name It: Formal Constitutionalism}

Taking a more positivist perspective, we assume that illiberal democracies emerging in Europe are still constitutional democracies, shaped peacefully by populist politicians from a more substantial form of constitutional democracy that prioritizes liberal constitutional values. After the transition, constitutional democracies in CEE pursued compliance with, or, depending on their national needs, even exceeded the minimum standards laid down by the rule-of-law, human rights, and democracy requirements in Europe under the aegis of the Council of Europe and the EU. ${ }^{75}$ A constitutional democracy requires a constitution, in a legal sense, that encompasses all the important principles which have arisen during Western European constitutional development as the core values of modern societies, such as the rule of law, human rights and democracy.

As a counter-effect of the socialist regime, legal procedures and legal constitutions were preferred in CEE over any other political considerations and approaches to the exercise of public power. These constitutions, based on the Kelsenian tradition and relying on the very notion and function of the legal understanding of a constitution, were seen as senseless unless able to be defended and enforced. A constitution or a constitutional setting without a written constitution like the UK, or the Treaty which we consider to be like a constitution for the EU, may be defended and enforced in many ways. Depending on the type of constitution, that is, whether it is a political concept, as defined by Bellamy concerning the UK, or a legal notion, which applies mostly in Europe, different procedures, like political processes such as elections and public discourse in the United Kingdom or institutions, such as constitutional courts in Hungary or Poland, ordinary courts in the Nordic countries or United States, or even council-of-state type institutions or a high degree of respect for international treaties like in the Netherlands, may be used for these purposes. In states with common-law traditions such as the UK, Canada, and New Zealand, the human rights charters or provisions are defended by the ordinary courts. ${ }^{76}$ Insofar as these instruments focus on the defense of individual human rights, a complying state should be called liberal, as this is the politico-philosophical stream which has raised human beings to the forefront of any public action. If a state is a constitutional democracy in Europe, theoretically, it does not need any adjective to express its commitment towards the rule of law, human rights—-not only civil and politicaland democracy.

An illiberal constitution and illiberal constitutionalism are the results of a peaceful constitutional development in which democracy, the rule of law, and human rights are not respected in the same way as before. ${ }^{77}$ In our understanding, this has little to do with the adjective itself, that is the politico-philosophical orientation of a constitution or a constitutional regime. ${ }^{78}$ What matters is the selective and arbitrary application of the constitution — in both Hungary and Poland-and the non-inclusive character of the constitution-making process in Hungary. This understanding of constitutional democracy suggests that-if we narrow our focus to encompass only the rule

\footnotetext{
${ }^{75}$ On these impacts in general, see Rett R. Ludwikowski, Supreme Law or Basic Law? The Decline of the Concept of Constitutional Supremacy, 9 CARDOZO J. INT'L \& COMP. L. 253 (2001).

${ }^{76}$ Stephen Gardbaum, The Case for the New Commonwealth Model of Constitutionalism, 14 GERMAN L.J. 2229 (2013).

${ }^{77}$ Similarly, see Marc F. Plattner, Populism, Pluralism, and Liberal Democracy, 21 J. Democracy 81, 91 (2010).

${ }^{78}$ We agree with the findings of David Collier \& Steven Levitsky, Democracy with Adjectives: Conceptual Innovation in Comparative Research, 49 WORLD POL. 430 (1997), and follow their thoughts on the need for parsimony in and avoidance of an excessive proliferation of new terms and concepts. In the field of continental European human rights protection, which should still be called liberal as it focuses on the individual, the active contribution of the state is required. This is referred to as institutional or objective protection provided by the state-see the jurisprudences of the constitutional courts in the regionor status positivus, as set out by Robert Alexy, The TheOry of CONSTITUTIONAL Rights (2002).
} 
of law, human rights, and democracy-these principles may have been defectively worded in a constitution, poorly implemented, or poorly enforced.

The problem lies here: These states are still constitutional democracies in a formal sense. Each one still has a constitution, which is more than the formal constitution of an autocratic system, as it, for example, maintains and allows the functioning, to a certain extent, of constitutional review mechanisms and is far less oppressive than the "real" authoritarian regimes. Both constitutions still contain EU clauses and formally maintain the rule of law and formal democracy in the majoritarian sense, though with no patience for procedural guarantees and individual rights. Simply, these states misuse the language of fundamental rights. The reasons for such disregard might be twofold. First, these matters might contradict the will of the majority, as argued by the leading populist parties. Second, they might slow down the decision-making process, which is expected to be fast and efficient in order to prove the capability and strength of the state and thus its populist leader. ${ }^{79}$ Both constitutions still provide for the constitutional protection of fundamental rights, but either offer a lower level of protection than the previous constitution ${ }^{80}$ or contradict international and European human right standards. ${ }^{81}$ Nonetheless, these issues are politically important ones; there is either no or considerably less depletion of the constitutional protection over the rights with minimal politcal implications.

Since the accession to the EU in 2004, the application of EU law has become a daily practice of the ordinary courts. Regardless of the regime change's reforms, the EU law could have slowed down the degradation but, as Bozóki and Hegedüs observe, it is not easy to demonstrate through examples how the constraining function of the EU works in practice. ${ }^{82}$ This is especially so because first, recent researchers focused on only the actions that have been made against the EU and international obligations, ${ }^{83}$ and second, we might have never known about the original plans of the populist leaders or the reasons why they gave them up. ${ }^{84}$ What we can note here is that there are some examples where the Hungarian and Polish decision-makers backed off. ${ }^{85}$

\footnotetext{
${ }^{79}$ Plattner, supra note 77 , at 88 .

${ }^{80}$ See in Hungary, for example, family, social security and the right to assembly, which can be restricted by the enjoyment of privacy, family life and home; Magyarország Alaptörvénye [The Fundamental Law of Hungary], Alaptörvény arts. L, XIX(1), VI [hereinafter Hungarian Fundamental Law]. The new Article VI was introduced by the Seventh Amendment on June 28, 2018.

${ }^{81}$ See, e.g., in Hungary: The right to religion, rules on migration, and the right to assembly; and in Poland: The right to privacy, Venice COMM'N, Opinion No. 839/2016 (June 13, 2016); the right to assembly; and exhibiting a preference for cyclical assemblies, Kp 1/17 of Mar. 16, 2017. As for the right to religion in Hungary, it is still the Hungarian Parliament and not independent courts who decide on whether a religious community can be viewed as an established church. Criteria are to be established by an Act, but no objective criteria are laid down and there is no real remedy against the decision of the Parliament. Despite the otherwise detailed rules, the FL does not give any guidance as to the content of these criteria. See also HUNGARIAN Fundamental LAW art. VII; Alkotmánybíróság (AB) [Constitutional Court], MK.6/2013 (Hung.); Magyar Keresztény Mennonita Egyház \& Others v. Hungary, Apps. Nos. 70945/11, 23611/12, 26998/12, 41150/12, 41155/12, 41463/12, 41553/12, 54977/12, \& 56581/12 para. 115 (Apr. 8 2014); TASZ, A JOGVÉDÖ SZERVEZET ÁLLASPONTJA AZ EGYHÁZÜGYI TÖRVÉNY MÓDOSÍTÁSÁNAK KONCEPCIÓJÁRÓL ÉS TERVEZETÉRÖL [The Standpoint of Hungarian Civil Liberties Unit on Human Rights Organization Concerning the Concept and Draft of the Modification of the Church Affairs Law] (2015), http://tasz.hu/files/tasz/imce/2015/egyhaztorveny_modositas_taszvelemeny_20151005.pdf; FORUM FOR RELIGIOUS FREEDOM, Hungary: Amended Church LaW Remains at Variance with OSCE Standards and the European Convention ON Human Rights (2015), =http://www.osce.org/odihr/186866?download=true; Venice ComM'N, Opinion No. 720/2013 (June 17, 2013); Hungarian Fundamental LaW arts. L, XXII(3); Drinóczi, supra note 1. As for migration, see Ilias \& Ahmed v. Hungary, App. No. 47287/15 (Mar. 14, 2017), http://hudoc.echr.coe.int/eng?i=001-172091.

${ }^{82}$ Bozóki \& Hegedüs, supra note 2 , at 180.

${ }^{83} \mathrm{Admittedly,} \mathrm{this} \mathrm{Article} \mathrm{aims} \mathrm{at} \mathrm{this} \mathrm{approach,} \mathrm{too.} \mathrm{For} \mathrm{an} \mathrm{overview,} \mathrm{it} \mathrm{is} \mathrm{worth} \mathrm{to} \mathrm{have} \mathrm{a} \mathrm{look} \mathrm{at} \mathrm{JAKAB} \mathrm{ANDRAS} \mathrm{\&}$ GajdusCHeK GYorgy, A MAgYAR JOGRENDSZER ÁLlapota [The state of the Hungarian legal system] (2016), https://jog. tk.mta.hu/uploads/files/A_magyar_jogrendszer_allapota_2016.pdf.

${ }^{84}$ For instance, there were rumors that when writing the new constitution, the Fidesz wanted to abolish the CC and locate the review function to one of the chambers of the Supreme Court.

${ }^{85}$ It happened with certain reforms regarding the decision-making process at the CT, the retirement age of the judges of the Supreme Court in Poland, and the introduction of the administrative court system in Hungary.
} 


\section{How to Create Illiberal Constitutionalism \\ 1. Capturing Constitutions and Constitutionalism}

Transformation of a regime starts with the alteration of its constitutional foundations. In our case, the governing parties started with the monopolization of the constitution-making and amending processes in Hungary, and claimed the final word in debates on the meaning of the constitution in Poland.

\section{Formal and Informal Ways of Constitutional Change}

In Hungary, all changes were made through the constitution-making and constitution-amending powers, which observed the established formal rules. In order to make any constitutional changes, a constitutional majority - that is, the support of two-thirds of the Members of Parliament-was all that was required. In Hungary, there has always been a prohibition on holding a referendum on constitutional amendments, ${ }^{86}$ which was extended to the adoption of the constitution. The claim that the new Fundamental Law of 2011 ("FL") could not be voted on in a referendum was based on this legal position. Consequently, neither the constitution-making process nor the constitutionamending process was inclusive. The first sign of the monopolization of these processes was the repeal of the four-fifths majority rule from the constitution in $2010 .^{87}$ It was a clear message that there was no need for any political support or consensus from the opposition, and it underlined the non-inclusive character of the constitution-changing and constitution-making processes.

The exclusion of the Polish political opposition from parliamentary sitting by the Marshal of the Sejm and changing the voting place-outside the main chamber and with restricted accessduring the legislative process in 2016, shows how the political majority, which holds itself out as the representative of the will of the nation, can act in an abusive way. Nevertheless, abusive constitutionalism, ${ }^{88}$ as understood by David Landau and employed in Hungary, has not been implemented in Poland. There, the winning political party did not gain a constitutional majority in the 2015 parliamentary elections. The government, however, continues to act in an unconstitutional way by informally ${ }^{89}$ changing the constitution through ordinary legislation. It bypassed the former amending procedures or invalidated parliamentary resolutions. ${ }^{90}$ Moreover, the government created a legal basis for not publishing the decisions of the Constitutional Tribunal of Poland ("CT"), which runs counter to its role in the Polish legal system and the constitutional obligation to publish judgments in the official journal. ${ }^{91}$

In Hungary, beyond the formal constitutional amendments made since 2010, an informal constitutional change can also be seen as a result of the constitutional interpretation of the

\footnotetext{
${ }^{86}$ It first appeared in a decision Alkotmánybíróság (AB) [Constitutional Court] Jan. 22, 1993, MK.2/1993 (Hung.); which was later incorporated into HUNGARIAN FUNDAMENTAL LAW art. 8.

${ }^{87}$ Hungarian Fundamental Law art. 24(5). A majority of four-fifths of the votes of the Members of Parliament was required to pass the parliamentary resolution specifying the detailed regulations for the preparation of the new Constitution. Thus, it does not require a supermajority for the adoption of the new Constitution, as has incorrectly been asserted in scholarly works. See, e.g., Tom Ginsberg, Arato on Constitution Making in Hungary and the 4/5 Rule, I-CONNECT BlOG (Apr. 6, 2011), http://www.iconnectblog.com/2011/04/arato-on-constitution-making-in-hungary-and-the45-rule/. This misunderstood concept, found in Miklos Bánkuti et al., Hungary's Illiberal Turn: Disabling the Constitution, 23 J. Democracy 138, 139 (2012), is used also by Tushnet, supra note 51.

${ }^{88}$ Landau, supra note 3.

${ }^{89}$ For a wider overview more recently, see, e.g., Richard Albert, How Unwritten Constitutional Norms Change Written Constitutions, 38 Dublin Univ. L. J. 387 (2015). Regarding Hungary, see Timea DrinÓCZI ET AL., FORMAL AND Informal Constitutional Amendments - National Report on Hungary (2018).

${ }^{90}$ This was the case with the appointment of judges of the Constitutional Tribunal.

${ }^{91}$ See, e.g., Venice COMM'N, Opinion No. 860/2016, 16 (Oct, 14-15, 2016); Agnieszka Bień-Kacała, Informal Constitutional Change. The Case of Poland, 6 PrZegląd Prawa Konstytucyjnego 199 (2017). Finally, the judgements of March 9, August 11, and November 7, 2016 (K 47/15, K 39/16, K 44/16) were published in June 2018 with the information in official journal (Dziennik Ustaw), however, that they were illegally delivered.
} 
Constitutional Court of Hungary (“CC") regarding the constitutional identity of Hungary. ${ }^{92}$ The $\mathrm{CC}$ declared that the constitutional identity of Hungary is based on the historical constitution, and that its protection is a duty of the state..$^{3}$ This interpretation has no legal source whatsoever in the text of the FL, but the decision of the CC was preceded by the clear expression of a distinct political intention, that is, the quota referendum initiated by the government and the failed Seventh Constitutional Amendment. ${ }^{94}$ This formal amendment would have constitutionalized measures that could have been activated against otherwise binding EU law. Amongst other matters, the notion of constitutional identity based on the historical constitution and its protection as a state obligation, along with the prohibition of the settlement of alien populations in the territory of Hungary, would have been added to the constitutional text. Even though this proposal did not receive the necessary constitutional majority to be passed as a formal amendment, the $\mathrm{CC}$, as noted, drew the very same conclusion from the FL. ${ }^{95}$ This informal constitutional change was formalized in June 2018. After the election, the Fidesz party regained its constitutional majority and returned to the usual technique: Its parliamentary majority adopted the Seventh Amendment of the FL. The above-mentioned provisions were resubmitted along with two other consitutional novelties. The first one was the constitutional limitations to the right to assembly-in the way that it can be outbalanced by the right to privacy, family life, and home. The other one intended to introduce a separate administrative court system - the future independency of which, once constitutied, is highly doubted.

The population has not questioned constitutional changes in Hungary or Poland. It seems that there is a new social contract-constitutional in Hungary and unconstitutional in Polandbetween leaders and voters which has not been challenged yet in elections or more serious and influential popular discontent. Apparently, the population still supports the regime, which, in turn, gives the populus what it wants: Stability and belonging, no matter how fallacious and illusory they are. ${ }^{96}$

\section{The Paradox of Unconstitutional Formal and Informal Constitutional Amendments}

Because Hungary used the mechanism of abusive constitutionalism, and both Hungary and Poland implemented informal constitutional amendments and displayed a tendency to bypass rules of constitutional reform, both states find themselves on the same side and amongst those countries whose commitment towards the basic values of the European community has become questionable. ${ }^{97}$ The issue here may be how we conceive of these informal constitutional changes. From a legal point of view it is clear: If the legislative power adopts an unconstitutional act that is used to informally change the meaning of the constitution, and there is no effective mechanism against this legislative action, this informal constitutional amendment is unconstitutional. Such

\footnotetext{
${ }^{92}$ Alkotmánybíróság (AB) [Constitutional Court] Dec. 5, 2016, MK.22/2016 (Hung.).

${ }^{93}$ Timea Drinóczi, Hungarian Constitutional Court: The Limits of EU Law in the Hungarian Legal System, 1 VIENNA J. INT'L Const. L. 139 (2017); Katalin Kelemen, The Hungarian Constitutional Court and the Concept of National Constitutional Identity, 15-16 IANUS - DiRITTO E FINANZA 23 (2017).

${ }^{94}$ Zoltan Szente, Analysis: The Controversial Anti-Migrant Referendum in Hungary is Invalid (May 18, 2017), https://blogiacl-aidc.org/2016-posts/2016/10/18/analysis-the-controversial-anti-migrant-referendum-in-hungary-is-invalid. As for the failed amendment, see, e.g., Gabor Halmai, Constitutional Court Decision on the Hungarian Government's Constitutional Identity Defense, EUR. U. INST. BLOG (Jan. 12, 2017), https://blogs.eui.eu/constitutionalism-politics-working-group/ constitutional-court-decison-hungarian-governments-constitutional-identity-defense/.

${ }^{95}$ This informal constitutional amendment by constitutional interpretation remains unique even in the context of the previously debated constitutional interpretations of the CC delivered before 2010. Even though the CC acted in the same way after 1990 and amended the constitution informally, in cases between 1990 and 2010, there was no clear and previously expressed political will as to the "new constitutional meaning," and there was at least some constitutional text the interpretation could be based on.

${ }^{96} \mathrm{Cf}$. the results of the Value research, supra note 11; Schwartz \& Bardi, supra note 12; Humphrey, supra note 28.

${ }^{97}$ Agnieszka Bień-Kacała, Poland within the EU: Dealing with Populist Agenda, 4 Osteuropa Recht 428 (2017).
} 
practices have the high potential to demolish the rule of law, democracy, and the protection of human rights - which is the practice in Poland. Dismantling these values is also possible by formally observing the text of the constitution on legislation and constitutional amendment, provided that it includes provisions which themselves are contrary to the rule of law, democracy, and human rights. This is the case in Hungary in relation to, for example, church regulation, same-sex marriage, and the criminalization of homelessness, and it potentially may apply to, for example, other rules on the family. ${ }^{98}$

If a constitutional court or a supreme court, in the course of its interpretation of the constitution, implements an informal amendment of the text-for example, the meaning of the constitution is changed as a result of the court's interpretation-the situation is more complex and far from clear. Constitutional interpretation does not raise the issue of whether the result of the interpretation is constitutional or unconstitutional, as compared to the actions of the political branches of government. Other questions should be asked, such as whether the result of the constitutional interpretation is justified on legal grounds and whether it remains in the domain of interpretation without creating new law. If it does not remain within the boundaries of interpretation, it becomes informal constitutional amendment, which nevertheless may be necessary and justified. Most importantly, this type of informal amendment tends to occur in states in transition of any kind, or those that experience considerable difficulty in passing amendments.

Even though the perception of the nature of an informal constitutional amendment by constitutional interpretation depends on many factors, ${ }^{99}$ its legitimacy is contingent on the subsequent actions of the court itself or of the political decision-maker: Whether they uphold the interpretation, whether parliament adjusts its laws to conform to the interpretation, or whether they overrule the interpretation entirely. In the short term, it is difficult to say that an informal constitutional amendment by interpretation inevitably has a detrimental effect on the rule of law, democracy, and human rights. But unfounded arguments and methods of interpretation, packed courts, and the possible contribution of the decision towards further reinforcing the political system could lead to the formation and strengthening of an illiberal democracy. An example is the decision of the CC on the constitutional identity of Hungary in 2016. The CC helped to "stock up" the FL with "unconstitutional rules" by not declaring them unconstitutional, ${ }^{100}$ and now is ready to carve in stone the exact same provisions, by bringing them together under the heading "Constitutional identity of Hungary" in connection with the rules on churches. Now, if the $\mathrm{CC}$ takes itself seriously in the future, it will have to revisit its dismissive position on the possibility of the substantive review of constitutional amendments, even in breach of the express constitutional rule allowing only procedural review. ${ }^{101}$ In this way, the Hungarian constitutional setting, which is not in harmony with the EU and international obligations in every respect, could end up carved in stone according to the will of the political decision-maker. ${ }^{102}$ And, the will of the political decision-maker was expressed by the Seventh Amendment in July, 2018 by constitutionalizing the informal constitutional amendment of the CC. This constitutional dialogue between the constitution-amending power and the CC exemplifies how the political puzzle has been put together by informal, and, when formal constitutionality can be created, formal means.

\section{The Relativization of the Rule of Law and Human Rights}

In both Hungary and Poland, the rule of law is respected, and its importance is proclaimed-so long as it's in the government's interest to do. This was featured in the process by which Hungary

\footnotetext{
${ }^{98}$ See Hungarian Fundamental Law arts. L, XXII(3); Drinóczi, supra note 1.

${ }^{99} \mathrm{See}$, for example, the concept of constitutional interpretation applied-what is required for an activist judge is surely unacceptable for a textualist.

${ }^{100}$ Drinóczi, supra note 1.

${ }^{101}$ Hungarian Fundamental Law art. S.

${ }^{102}$ Drinóczi, supra note 93.
} 
adopted unconstitutional constitutional amendments like the Fourth Amendment of the FL; the procedure was legal, as the government used the formal amendment processes, but these processes were substantially contrary to previous decisions of the CC, such as those involving criminalization of homelessness, the definition of the family, and the removal of cases from the judge assigned. The government explained this systematic overruling of CC decisions as a mere "revisiting" of the ideas that appeared in these rulings. Even if the government argued in its communication with the Venice Commission ("VC") that none of the provisions of the Fourth Amendment amounted to a word-by-word copy of the annulled provisions, ${ }^{103}$ their exact content appeared in the constitutional text. In other quite limited cases, the government acted partly as was suggested by the VC, like on the judiciary. ${ }^{104}$ The Polish political decision-maker, however, due to the lack of a constitutional majority, was not able to amend the constitution but provided interpretations to support its agenda. This was the case regarding the law on the $\mathrm{CT}$, the appointment of constitutional judges, and the non-publication of CT judgments. The government was not bothered by the fact that its interpretations were completely different from those previously provided by the CT, or reiterated by the VC and the European Commission. Moreover, the government views its interpretations as final and decisive. According to the Polish Government, it was the CT that violated the constitution, and the adoption of the European Commission's recommendation would be contrary to the constitution. It has even contested the Commission's statement, according to which the CT was an essential safeguard of the rule of law in Poland. ${ }^{105}$

By these techniques, which affect the functioning of the CC and CT, the political majorities can successfully relativize the constitution and the principles of the rule of law, democracy, and human rights. The rule of law and human rights do not prevail if the CC and CT cannot properly fulfil their tasks. What prevails is the strong reference to the principles of democracy and popular sovereignty, insofar as they either remain formal or can be heavily influenced by undue measures, such as manipulative billboard campaigns and national consultations. ${ }^{106}$ This justifies all of the government's actions, no matter what kind of obligations eventuate at the international and supranational levels. The manipulated will of the people cannot be outweighed by the rule of law or human rights considerations, because, as the political majorities argue, those concerns would impose undue constraints on the popular sovereignty. Governance, however, is not about governance by, for, or of the people anymore; rather, it refers to the hegemony of a democratically elected party. ${ }^{107}$ Yet, as said, in Hungary and Poland, the leading political forces are still supported. The question now is how it is possible to gain and maintain that much political support.

\section{Constitutionalization of Populist Nationalism, Identity Politics, and Constitutional Identity}

Populist nationalist rhetoric and identity politics seem to be the primary forms of political legitimization in use at present. Nevertheless, in spite of the presence and emergence of populism in Europe, populists have thus far gained and maintained political power, mainly in the CEE region. ${ }^{108}$

\footnotetext{
${ }^{103}$ Comments of the Government of Hungary on the Draft Opinion on the Fourth Amendment to the Fundamental Law of Hungary 9-10 (CD-Ref(2013)034; 14 June 2013).

${ }^{104}$ Drinóczi, supra note 1.

${ }^{105}$ Considering the judicial reform of the summer of 2017, we can view a similar tendency in Hungary.

${ }^{106}$ Timea Drinóczi \& Ágoston Mohay, Has the Migration Crisis Challenged the Concept of the Protection of the Human Rights of Migrants? The Case of Ilias \& Ahmed v. Hungary, in Irregular Migrations as a Challenge For DEMOCRACY 97 (Elżbieta Kużelewska, Amy Weatherburn, \& Dariusz Kloza eds., 2018).

${ }^{107}$ See also Ruprik, supra note 6, at 80.

${ }^{108}$ Ruprik, supra note 6, at 78. This danger was successfully averted by voters in 2016 in Austria and in 2017 in the Netherlands and France.
} 
Today's populists, in line with the above-mentioned twisted concepts of democracy and popular sovereignty, tend to see the people or the nation as a homogeneous or uniform group. ${ }^{109}$ Even constitutions are formulated to encapsulate both the political nation ${ }^{110}$ and the cultural nation. ${ }^{111}$ Membership of the cultural nation and national ethnicityHungarian or Polish-has been repeatedly emphasized during the migration crisis ${ }^{112}$ and when drafting new laws. ${ }^{113}$ In Hungary, the redesign of the electoral rules with the assistance of the CC, and the highly preferential acquisition of Hungarian citizenship by those having Hungarian origin living abroad, led to the two-thirds election victory of the Fidesz Party in 2014. ${ }^{114}$ In addition, those who are different are viewed as enemies ${ }^{115}$ and are either demonized or victimized. While Hungary successfully demonizes migrants, ${ }^{116}$ and recently the LGBTQ community, in Poland, the parliamentary opposition is excluded from participating in the working sessions of the Sejm due to its allegedly obstructive actions. Victimization is also a common practice. There have been legal proceedings against Hungarian civil society

\footnotetext{
${ }^{109}$ Müller, supra note 31; Plattner, supra note 77 , at 88 .

${ }^{110}$ Hungarian Fundamental Law art. B (regarding people); Konstytucja Rzeczypospolitej Polskiej [Constitution of Poland] art. 4 (regarding nation) [hereinafter Polish Constitution].

${ }^{111}$ Preambles and other constitutional provisions concerning Polish/Hungarian ethnicity.

${ }^{112}$ See, e.g., the Hungarian billboard campaign on the migration threat in 2015 and the subsequent referendum on the "EU quota decision," Council Decision 2015/1601, 2015 O.J. (L 248/80) (EU), in 2016, and the ombudsman's petition to the CC in December 2015 against this Council Decision, which resulted in Alkotmánybíróság (AB) [Constitutional Court] Dec. 5, 2016, MK.22/2016 (Hung.), and the failed Seventh Amendment. See also ECJ, Joined Cases 643/15 \& 647/15, Slovak Republic \& Hungary v. Council of the European Union, ECLI:EU:C:2017:631 Judgement of 6 Sept. 2017 (concluding that the Hungarian and Slovakian claims were rejected).

${ }^{113}$ See, e.g., the new billboard campaign against the Soros Plan—to relocate migrants from Africa and Middle East; Budapest Business Journal, Hungarian gov't begins all-out assault on Soros, BUDAPEST BUSINESS JournaL (Sept. 28, 2017), https://bbj. hu/politics/hungarian-govt-begins-all-out-assault-on-soros_139438; and the accompanying legislation, or the law on foreignfunded non-governmental organizations (NGOs), adopted on June 13, 2017, which introduces new obligations for certain categories of NGOs receiving annual foreign funding above HUF7.2 million-approximately $€ 24,000$ — to register and label themselves in all their publications, websites, and press material as "organizations supported from abroad," and to report specific information about the funding they receive from abroad to the Hungarian authorities. These organizations face sanctions if they fail to comply with the new reporting and transparency obligations. This law triggered an infringement procedure. See European Commission, Infringements - Hungary: Commission launches infringement procedure for law on foreign-funded NGOs, Eur. Comm. NEwsroom (July 13, 2017), http://ec.europa.eu/newsroom/just/item-detail.cfm?item_id=118883. In the case of Poland, such an approach can be seen in connection to "defamation of Polish nation" legislation lately triggering tensions between Poland and the USA, Poland and Israel, and Poland and Ukraine, see Aleksandra Gliszczyńska-Grabias \& Anna Śledzińska-Simon, Victimhood of the Nation as a Legally Protected Value in Transitional States - Poland as a Case Study (Feb. 12, 2018), https://ssrn.com/abstract=3120407 (unpublished manuscript); Wojciech Sadurski, The Holocaust Law Triggers Unanticipated Consequences, I-CONNECT (Mar. 14, 2018), http://www.iconnectblog.com/2018/03/ the-holocaust-law-triggers-unanticipated-consequences; Alina Cherviatsova, Memory Wars: The Polish-Ukrainian Battle about History, VERFBLOG (Feb. 9, 2018), https://verfassungsblog.de/memory-wars-the-polish-ukrainian-battle-abouthistory/.

${ }^{114}$ Republikon Institute, Hungarian Elections 2014: Turnout and the Impact of the Electoral System, 4 LIBERTY.EU (May 9, 2014), http://4liberty.eu/republikon-institute-election-2014-turnout-and-the-impact-of-the-electoral-system/; Alkotmánybíróság (AB) [Constitutional Court] Dec. 5, 2016, MK.3141/2014 (Hung.).

${ }^{115}$ Plattner, supra note 77 , at 88; Diamond, supra note 60, at 149.

${ }^{116}$ According to the Spring 2016 Global Attitudes Survey, although many Europeans were concerned with security and the economic repercussions of the refugee crisis, Hungarians made it to the top of the list, despite the facts that no terror attack has taken place in Hungary and that Hungary is neither the destination country for migration nor a Mediterranean country. Hungarians scored highest in relation to statements that "refugees will increase the likelihood of terrorism in our country" with $76 \%$, "refugees are a burden on our country because they take our jobs and social benefits" with $82 \%$, and "refugees in our country are more to blame for crime than other groups" with $43 \%$. To offer a comparative perspective, in those countries which do indeed have a high migrant population, and which have already suffered terror attacks, the figures are as follows: Germany: 61\%, 31\%, 35\%; France: 46\%, 53\%, 27\%. R. Wike, B. Stokes, and K. Simmons, Europeans Fear Wave of Refugees Will Mean More Terrorism, Fewer Jobs. Sharp ideological divides across EU on views about minorities, diversity and national identity, 3 https://www.pewresearch.org/global/2016/07/11/europeans-fear-wave-of-refugees-will-mean-more-terrorism-fewerjobs/ (July 11 2016).
} 
upon the order of the Prime Minister, ${ }^{117}$ and legal procedures against Polish protesters too, ${ }^{118}$ who are occasionally harassed by the police. ${ }^{119}$

Moreover, there is also new criminal legislation that criminalizes the assistance provided for asylum-seekers by NGOs and violates the human rights of those who enter Hungary illegally, ${ }^{120}$ and there is an emerging violence in Poland towards foreigners, for example entrepreneurs, and students-especially those who look different or who speak other languages. ${ }^{121}$ The measures used for such demonization and victimization, save for the street violence, are formally legal. This legal fight against migrants and foreigners, or against those who hold opposing views, is presented as a legitimate counteraction against the chaos caused by these individuals and the threat they allegedly pose to security and stability. Populist leaders put themselves forward as being able to restore order-the disorder itself usually being generated by those same populist leaders with their nationalist politics. ${ }^{122}$ Because the problem is often incorrectly identified, because there might not be a problem at all, or because its focal point lies elsewhere, challenges cannot be adequately addressed, and a legal solution acceptable to the wider environment, that is, the international community or the EU, cannot be found.

A ramification of populism is a new form of identity politics, which is emerging especially in Hungary, and finds its legal basis in Article 4(2) of the TEU and in the FL. ${ }^{123}$ The main message of the Hungarian constitution is that Hungarian constitutional identity is to be found in the past through the historical constitution, and it should be defended against undue influences such as EU legislation-even though the Council Decision on relocation was not considered annulled- ${ }^{124}$ or against any exaggerated and unrealistic attempt to alter the "ethnic map" of Hungary $^{125}$. Identity politics thus have an ethnic implication and an exclusive character as well. Its success may also be supported by historical and societal factors. ${ }^{126}$

Both populist nationalism and identity politics play with the emotions and exclude rationality. According to András Sajó, "emotional politics refers to a situation where the politics is shaped by emotional manipulation of the masses." 127 This kind of politics has been described as one of the threats to the CEE after the transition period, ${ }^{128}$ but, as can be seen, it features in today's politics as well.

\footnotetext{
${ }^{117}$ Hungary new Bill aims to silence civil society that criticizes the state, (8 May 2017) https://www.civicus.org/index.php/ media-resources/news/interviews/2835-hungary-new-bill-aims-to-silence-civil-society-that-criticises-the-state.

${ }^{118}$ Gazeta Wyborcza, Ponad 600 postępowań wobec uczestników antyrządowych protestów, POLSAT News (Nov. 20, 2017), http://www.polsatnews.pl/wiadomosc/2017-11-20/ponad-600-postepowan-wobec-uczestnikow-antyrzadowych-protestow/.

${ }^{119}$ W prost, Policja publikuje zdjecia protestujacych pod Sejmem, WProst (Jan. 19, 2017), https://www.wprost.pl/kraj/ 10039339/Policja-publikuje-zdjecia-protestujacych-pod-Sejmem-To-skandal-zastraszanie-obywateli.html.

${ }^{120}$ Timea Drinóczi, Special Legal Orders: Challenges and Solutions, 62 Osteuropa Recht 420 (2016); Ilias \& Ahmed, App. No. $47287 / 15$.

${ }^{121}$ Polityka, Nawet sto ataków na obcokrajowców dziennie - tak w Polsce kwitnie ksenofobia, POLITYKA (June 29, 2017), https://www.polityka.pl/tygodnikpolityka/spoleczenstwo/1710550,1,nawet-sto-atakow-na-obcokrajowcow-dziennie-tak-wpolsce-kwitnie-ksenofobia.read.

${ }^{122}$ It is visible especially in an international or a national context. Daniel W. Drezner, The Angry Populist as Foreign Policy Leader: Real Change or Just Hot Air, 41 Fletcher F. World AfF. 23 (2017).

${ }^{123}$ Alkotmánybíróság (AB) [Constitutional Court] Dec. 5, 2016, MK.22/2016 (Hung.).

${ }^{124}$ ECJ, Joined Cases C-643/15 \& C-647/15, Slovak Republic \& Hungary v. Council, ECLI:EU:C:2017:631, Judgment of 6 Sept. 2015.

125"We insist on the ethnic and cultural composition of Hungary," said the Prime Minister. See https://www.kormany.hu/ hu/a-miniszterelnok/beszedek-publikaciok-interjuk/orban-viktor-beszede-a-kulkepviselet-vezetok-ertekezleten-2015. This is the basis of all the legislation against refugees-the Soros Plan and the NGOs that allegedly are working on the execution of the Soros Plan. The court decided that the inclusion of the Helsinki Committee in the explanatory part of the national consultation on the Soros Plan was illegal as it infringes the right to good reputation.

${ }^{126}$ As Rupik states, it has deep historical resonance in the CEE societies, because there, as opposed to Western Europe, no post-colonial complex was experienced that would have opened up society to diversity. Ruprik, supra note 6 , at 84 . For the elaboration of other non-legal reasons, see Drinóczi \& Bień-Kacała, supra note 5.

${ }^{127}$ Andras Sajó, Militant Democracy and Emotional Politics, 19 Constellations 563 (2012)

${ }^{128}$ Andras Sajó, Militant Democracy and Transition Towards Democracy, in Militant Democracy 217, 218 (Andras Sajó ed., 2004).
} 
Such emotional politics allow for the replacement of the rule of law with the "verdict of the people." Instead, the Weberian sense of rationalism should be a component of a constitutional democracy, as it limits and even moulds the decision-making process. This is present neither in Hungary nor in Poland, where there is no sign of pursuit of rational, or even constitutional, legislation. It is apparently not demanded by the population, whose value orientation prioratizes authoriarianism, in the sense of blind submission to authority and preference to hierarchy and stability.

\section{New Patrimonialism, Clientelism, and State-Controlled Corruption}

Illiberalism also entails legally supported new patrimonialism and clientelism, ${ }^{129}$ and statecontrolled corruption, which adds up to creating a "corrupt oligarchy" 130 or mafia-state. ${ }^{131}$ Populist leaders accumulate wealth and power for themselves and their families, their clients, and their parties. ${ }^{132}$ According to Transparency International's Corruption Perceptions Index 2016, Hungary ranked 57th in 2016 and 64th in 2018, displaying substantial backsliding since 2012, when the FL entered into force. Hungary has dropped three points since 2015 and is the fourth most corrupt country in the EU. Poland ranked 29th in 2015 and 2016 and ranked 36th in 2018, and its scores display a slight deterioration since 2015. ${ }^{133}$ Corruption in Hungary presents a significant risk to business, particularly in the tax administration and public procurement sectors that suffer from high levels of corruption. ${ }^{134}$ The possibility of corruption in Hungary is inherent in the state's legal rules and culture. It is still to be seen if Poland will keep following Hungary in dropping in the Corruption Index rankings.

For creating an incumbent-friendly legal environment, an empowered executive is necessary in order to capture the parliamentary majority in a parliamentary system. In Hungary, presidentialization of the executive power has taken place since 2010: The state has been evermore governed by the principles of statism. The centralization of political governance has prevailed even more than before, and media-marketing governance has emerged. ${ }^{135}$ This led to the personalization of politics, and produced a charismatic leader in whom voters believe. In Poland, because of the different political situation in which the actual political leader is not the head of the government, the rationalized parliamentary system has been altered: Substantial power is given to some Ministers, such as Defence Ministers ${ }^{136}$ and Justice

\footnotetext{
${ }^{129}$ Diamond, supra note 60, at 149; see also Henry E. Hale, 25 Years After The USSR: What's Gone Wrong?, 27 J. DEMOCRACY 24 (2016).

${ }^{130}$ See Jan Puhl, A Whiff of Corruption in Orbán's Hungary, SPIEGEL (Jan. 17, 2017), http://www.spiegel.de/international/ europe/a-whiff-of-corruption-in-orban-s-hungary-a-1129713.html.

${ }^{131}$ MAgYAR, supra note 10.

${ }^{132}$ See Diamond, supra note 60, at 149 . The most visible example is Mr. Misiewicz, a spokesman for the Defense Ministry, who has no professional experience; or an example from Hungary may be the case of Baka v. Hungary, App. No. 20261/12 (June 23, 2016), =http://hudoc.echr.coe.int/eng?i=001-163113.

${ }^{133}$ Hungary scored 46 in 2016; 51 in 2015; 54 in 2014; 54 in 2013; and 55 in 2012. Poland scored 62 in 2016; 63 in 2015; 61 in 2014; 60 in 2013; and 58 in 2012. The survey ranks some 176 countries and uses a scale of 0 — highly corrupt—to 100 — very clean. See Transparency International, Corruption Perceptions Index 2016 (Jan. 25, 2017), https://www.transparency.org/news/ feature/corruption_perceptions_index_2016. See also Hungarian Spectrum, Olaf Tag (Sept. 4, 2019), http:// hungarianspectrum.org/tag/olaf/ and ABOut Hungary, Olaf(Jan. 3, 2018), http://abouthungary.hu/olaf/. For the 2018 index, see Transparency International, Corruption Perceptions Index 2018(2018), https://www.transparency.org/cpi2018.

${ }^{134}$ GAN Integrity, Hungary Corruption Report (Nov. 2017), https://www.business-anti-corruption.com/country-profiles/ hungary.

${ }^{135}$ Tamas Sárközy, Magyarország kormányzása 2010-2014 [Governance of Hungary 2010-2014] 2 ÚJ MAGYAR KöZIgAZgAtÁs (2015); Istvan Stumpf, A kormány alkotmányos jogállása [Constitutional status of the Government], 2 Új MAGYar KÖZigazGatás (2015).

${ }^{136}$ It was true especially up until December 2017, when members of the government were changed. The current Minister of Defense is less strong and controversial.
} 
Ministers, and to the leader of the ruling party. In this construction, the Prime Minister and the President of the Republic have only secondary roles.

Building a neo-patrimonial system had two major effects in the states at issue. The first is that Hungarian legislation remains defective, and Polish legislation has definitely deteriorated: ${ }^{137}$ There is no political will to take advantage of rational or evidence-based legislation, and there is no genuine consultation ${ }^{138}$ with civil society and various stakeholders. Both the Hungarian and Polish legislation may be characterized by hyperactivity, neo-Macchiavelism, and an ad hoc nature.

The second effect is that checks and balances are eroding. Rules governing the election or nomination of candidates for independent positions continue to be subject to change in Hungary and Poland, and misused in Poland. Even though these new provisions may be applauded at first sight and are even complied with, they cannot operate as effective mechanisms to avoid abuse and concentration of power. These reforms are reasonable only on the surface. They could potentially compromise independent institutions, such as the Prosecutor General, and the ordinary and constitutional courts. Judicial reforms have been aimed at appointing more loyal staff into the highest ranks and management positions of the courts by changing the retirement age with ex nunc effect in Hungary ${ }^{139}$ and centralizing the appointment process in Poland. ${ }^{140}$

The Hungarian reforms on the nomination of CC judges and the constitutional position of the Hungarian Prosecutor General may prove to be a double-edged sword. The principal ideas behind the change to the nomination process sought to ensure the continuous functioning of the CC by avoiding previous political blockages and transforming it into a more juridical-type organ, which are legitimate goals. The means chosen, however, are not acceptable, as they exclude any possibility of political compromise by monopolizing the nomination process. The parliamentary committee that decides on each nomination is now formed proportionally by Members of Parliament. Previously, each parliamentary faction could send an equal number of representatives to this committee. The Prosecutor General is now elected for nine years by a two-thirds majority of Parliament. The mandate terminates with the lapse of time, but the incumbent Prosecutor General can continue to act until the new Prosecutor General is elected. Extension of the mandate could serve a legitimate goal — that is, to prevent any vacancy caused by political disagreement. It has another effect as well: It can keep loyal personnel in power for a very long time, which would run counter to the logic of the temporal division of power. As a result of the Seventh Amendment of the FL, a separate administrative court system will be created which can jeopardize judicial independency and frustrate political participatory rights.

In Poland, judicial reform has resulted in a hierarchical structure and subordination of the prosecutors to the Minister of Justice, who serves simultaneously as the Prosecutor General. This has created an illegitimately strong instrument with which the ruling party is able to monitor

\footnotetext{
${ }^{137}$ Timea Drinóczi, Ex Post Assessment of Legislation in a Comparative Context: CEE and Balkan, 10-1 KLRI J. LEGIS. Evaluation 127 (2016). In 2015, when the referred paper on ex post assessment was written, Poland could be viewed as a model country for implementing better regulatory policies, such as impact assessments. When legislation is driven by mere political considerations, however, irrespective of its constitutionality, no such quality can be found.

${ }^{138}$ The national consultation conducted by the Hungarian Government is not considered a genuine consultation but a manipulative maneuver.

${ }^{139}$ See, for example, Alkotmánybíróság (AB) [Constitutional Court] July 17, 2012, MK.33/2012 (Hung.), which declared the unconstitutionality of the rule. Even so, the affected judges could not regain their positions as they had already been filled. See also, Timea Drinóczi, Temporal Effects of Decisions of the Hungarian Constitutional Court, in THE EFFECTS OF JUDICIAL DeCisions IN Time 77, 87-106 (Patricia Popelier et al eds., 2014). In ECJ, C-286/12, European Commission v. Hungary, ECLI:EU:C:2012:687, Judgment of 6 Nov. 2012, the court declared that by adopting a national scheme requiring the compulsory retirement of judges, prosecutors, and notaries when they reach the age of 62 -which gives rise to a difference in treatment on grounds of age which is not proportionate as regards the objectives pursued-Hungary had failed to fulfil its obligations under Council Directive 2000/78 of Nov. 27, 2000, Establishing a General Framework for Equal Treatment in Employment and Occupation, arts. 2, 6(1), 2000 O.J. (L 303) 16 (EC).

${ }^{140}$ The most visible example is dismissal and attempted dismissal of presidents of Supreme Courts-A. Baka and M. Gersdorf-before the constitutional terms of office expired.
} 
the political opposition and civil society. ${ }^{141}$ Because of the new law on the judiciary, ${ }^{142}$ an extremely undemocratic concentration of power has been established in Poland.

It is not unusual for newly elected or appointed persons to have remained politically biased and sometimes for them to be less qualified than they are politically reliable. The Polish CT judge Lech Morawski said in 2017 that he represented the position of the CT and simultaneously the Polish Government. Likewise, the former President of the Hungarian CC declared in 2015 that the CC would be an engine of governance. ${ }^{143}$ Others who have been appointed or elected have been criticized because of their well-known personal relationship with the Hungarian Prime Minister and their loyalty to the leader of the ruling PiS party. The Hungarian CC is a partner of the governing party. Its Polish counterpart is rather a victim of the reforms, but it could become the future partner of the government. The result is that constitutional courts do not take the constitutions into account but serve the will of the governments. ${ }^{144}$ It also happens that their decisions are not considered at all. ${ }^{145}$ This practice has already been theorized by scholars in both countries, which we elaborate in the section following.

\section{Capturing Constitutionalism - Misunderstanding of Political Constitutionalism}

When theorizing on the activity of political decision-makers in both Hungary and Poland, there is common reference to the misunderstood concept of political constitutionalism and the supremacy of the parliament, along with misguided interpretation of the concept of state sovereignty. Hungarian and Polish scholars started to develop the idea that political constitutionalism prevails over legal constitutionalism in these states. These scholars, however, neglected to consider whether the constitutional, political, and social preconditions of political constitutionalism are present in their states, or whether there are fundamental differences between these two kinds of constitutionalism. ${ }^{146}$

\footnotetext{
${ }^{141}$ As for the positioning of the Prosecutor General in a constitutional system, various models are available, and states opt for variations which best fit their particular legal system. Nevertheless, there are certain criteria that should be observed, but which the Polish model does not seem to fulfil. See Council of Europe, Compilation of Venice Commission Opinions And Reports Concerning Prosecutors 23-26 (2015).

${ }^{142}$ Prawo o ustroju sądów powszechnych [Law on Common Courts] (2001 r. DZ. U. z 2018 r. poz. 3 i 23) (Pol.).

${ }^{143}$ An Oxford symposium on the Polish constitutional crisis sparks public debate, OXFord UNIVERSITY (May 12, 2017), https://www.law.ox.ac.uk/news/2017-05-11-oxford-symposium-polish-constitutional-crisis-sparks-public-debate; Chief Justice Lenkovics on the Fidesz Constitutional Court, Part I, Hungarian SPectrum (May 18, 2017), http:// hungarianspectrum.org/2015/07/18/chief-justice-lenkovics-on-the-fidesz-constitutional-court-part-i/.

${ }^{144}$ Concerning Hungary, see Alkotmánybíróság (AB) [Constitutional Court] Dec. 5, 2016, MK.22/2016 (Hung.) and Alkotmánybíróság (AB) [Constitutional Court] July 15, 2014 MK.3194/2014 (Hung.), on the monopolization of the retail trade in tobacco products. The right of those formerly carrying out tobacco retail activities was restricted, and in the future, they could continue their business only if they received a concession, the number of tenders available being very limited. The objective criterion of a kind of numerus clausus was considered to be a subjective limitation, allowing more room for the legislative power to restrict the fundamental right to enterprise. On Poland, see Wyrok [Judgment] Trybunal Konstytucyjny [Polish Constitutional Tribunal] June 20, 2017, K 5/17, on the National Council of Judiciary (NCJ). The CT provided justification for future NCJ restructuration based on rereading constitutional provisions.

${ }^{145}$ See, e.g., Poland Wyrok [Judgment] Trybunal Konstytucyjny [Polish Constitutional Tribunal] Mar. 9, 2016, K 47/15; Wyrok [Judgment] Trybunal Konstytucyjny [Polish Constitutional Tribunal] Aug. 11, 2016, K 39/16; Wyrok [Judgment] Trybunal Konstytucyjny [Polish Constitutional Tribunal] Nov. 7, 2016, K 44/16; Hungarian Fundamental LAW art. 24(5).

${ }^{146}$ In Hungary, some authors describe the period of 1990-2010 as constituting a legal constitutionalism and the period following 2010 a political constitutionalism. See Timea Drinóczi, Does the Constitutional Review Breach the Principle of Separation of Powers? A Shifting Perspective, in New Developments in Constitutional Law. EsSAYS In HonOur OF ANDrÁs Sajó 75 (I. Motoc et al, eds., 2018). Some Polish authors, while trying to justify the government's position, claim that the will of the people and, in consequence, justice, is more important than the law and that the republican view must take precedence. B. Szmulik, Opinia w sprawie uwag do nowelizacji ustawy z dnia 25 czerwca 2015 r. o Trybunale Konstytucyjnym przygotowanych przez Komisję Wenecka [Opinion on the comments on the amendment of the Act of 25 June 2015 on the Constitutional Tribunal by the Venice Commission], 5 PrZegląd SejMOWY 81 (2016); Adam Czarnota, The Constitutional Tribunal, VerfBlog (June 3, 2017), http://verfassungsblog. de/the-constitutional-tribunal/; Lech Morawski, A Critical Response, VerFBLOG (June 3, 2017), http://verfassungsblog.de/acritical-response/.
} 
Richard Bellamy ${ }^{147}$ assumes that legal constitutionalists try to constrain democracy by referring to and applying superior constitutional rules, undermining legitimacy and the efficacy of law and the courts. For legal constitutionalists, it is the constitution that represents a fundamental structure for reaching collective decisions in a democratic way. The constitution is a legal document that is binding on all, and which is protected by constitutional review mechanisms. Political constitutionalists, however, see the constitution differently: For them, the constitution is the democratic process itself, and it is a political, rather than legal, system. Thus, in their view, the constitution is not treated as a basic norm. Disagreements are to be resolved within this political framework, which obviously rejects the idea of any kind of review conducted not by political, but by independent and unelected, but otherwise selected, actors such as judges.

If we seek to apply any typology to both the Hungarian FL and the Polish Constitution, or to their constitutional practice since 2010 or 2015 , it is misleading to employ the theory of political constitutionalism, mostly because it may lead us to the ill-founded impression that the prerequisites of political constitutionalism are also valid in these states, and that we do not have a legal constitution but a political one, which is not true either de facto or de iure. The Hungarian and Polish constitutions are the products of a constitution-making process, even if the Hungarian process can justifiably be criticized. This fact alone makes them written constitutions that, according to their own rules, are the foundation of their legal systems, binding on everyone, including the state power. ${ }^{148}$ This means that each constitution is viewed as a legal document and not as a political process. This is also the reason why the constitutions prescribe the $\mathrm{CC}$ and the CT respectively ${ }^{149}$ as the primary organs for their protection. Indeed, neither the political nor the social preconditions and guarantees of political constitutionalism - such as political commmitment and competetion - are present in Hungary: Electoral rules considerably favor the ruling party, and serious defects exist in both Hungary and Poland as regards genuine participation in the legislative processes. The current approaches of both Hungary and Poland are, in fact, more similar to those of the socialist systems under the 1949 Hungarian Constitution and the 1952 Polish Constitution, both of which lasted until the fall of the Soviet Union in 1989, ${ }^{150}$ than to the requirements of political constitutionalism. During the Soviet era, these states implemented something we call "political will supremacy." According to the socialist constitutions, the most important social and political actor was the socialist party, which had a huge and exclusive impact on the functioning of state organs, including the state parliament. This was exactly why the constitutional courts of the post-socialist states were empowered to defend the constitution and annul all legal acts they deemed unconstitutional, without giving any power to overrule to parliament.

This kind of indoctrination, which marks the emergence of political constitutionalism in these states and which is present in scholarly works in support of the government position, may also be destructive.

\section{E. Are There Plausible Variations of Retransformation?}

Against this background, we think that both Hungary and Poland have already become so advanced in their illiberal constitutionalism that the system can be considered stable. Public law mechanisms existing in liberal democracies and advocated by the literature to re-transform illiberal systems do not seem to be effective. Once they are in illiberal hands, they may serve to

\footnotetext{
${ }^{147}$ Richard Bellamy, Political Constitutionalism: A Republican Defence of the Constitutionality of DEMOCRACY 2-5 (2007).

${ }^{148}$ Drinóczi, supra note 146.

${ }^{149}$ Compare Hungarian Fundamental Law art. 24, with Polish Constitution art. 188.

${ }^{150}$ Paul Blokker calls it communitarian constitutionalism. Paul Blokker, From legal to political constitutionalism?, VERFBLOG (June 4, 2017), http://verfassungsblog.de/from-legal-to-political-constitutionalism/.
} 
consolidate existing illiberal systems. There are several plausible solutions that could be tested, but which, unfortunately, would prove to be inefficient. ${ }^{151}$

First, we could investigate whether the concept of militant democracy ${ }^{152}$ might help to defeat illiberal democracy, as a liberal democracy is supposed to employ efficient measures to defend itself. This may not work because a constitutional democracy cannot use unconstitutional measures in defending itself, as at that very moment it ceases to be a constitutional democracy. Second, even though both the separation of powers and the rule of law formally exist, they de facto do not prevail. In such circumstances, only substantial nationwide political discontent or civil disobedience may constitute a kind of remedy. The success of either of these in a peaceful manner is also questionable due to populist politics, which discredited democratic institutions but still enjoy popular support. Thus, the instruments of militant democracy, despite civil resistance, are disabled because they ought to be launched predominantly by the state authorities.

Granting a role to the EU process of safeguarding European values might be considered as a second possibility. The EU has so far failed in this respect, ${ }^{153}$ but the Article 7 procedure against Poland and Hungary, and the new mechanism linking EU funds to rule of law compliance, may prove otherwise. The Rule of Law Framework Mechanism proved to be a clear failure. ${ }^{154}$ Soft law mechanisms of the Council of Europe have no effect either.

A third potential solution to the problems of liberal democratic decay is offered by Rosalind Dixon and David Landau. They propose that courts should evaluate the constitutionality of constitutional changes against the standard of transnational norms in democratic constitutions. ${ }^{155}$ If, however, the courts are packed, paralyzed, or corrupt, it is highly doubtful that they would take advantage of any transnational rules.

As another, more country-specific alternative, there is a tempting view which has emerged in Poland, according to which ordinary courts should take over the competence of constitutional review from the paralyzed CT. ${ }^{156}$ Those suggesting this method argue that the primary constitutional values are the supremacy of the Constitution and the separation of powers. According to these principles, the judiciary is recognized as a balancing mechanism and as a constraint on unconstitutional actions of the legislature. If the CT is disabled, the ordinary courts should take over constitutional review-without, however, repealing laws - as they review the consistency of laws with international obligations and secondary EU acts. ${ }^{157}$ It is argued that the emergency situation caused by the actions through which the CT was paralyzed justified institutional changes with regard to constitutional review: That ordinary courts should conduct constitutional review instead of the CT-emergency judicial review. ${ }^{158}$ Nevertheless, in a captured constitutional

\footnotetext{
${ }^{151}$ This is elaborated further in Drinóczi \& Bień-Kacała, supra note 5.

${ }^{152}$ See, e.g., Jan-Werner Müller, Militant Democracy, in The OXford Handbook of Comparative Constitutional Law 1253 (Michel Rosenfeld \& Andras Sajó eds., 2012); Patrick Macklem, Militant democracy, legal pluralism, and the paradox of self-determination, 4 INT'L J. ConsT. L. 488 (2006); Sajó, supra notes 127, 128.

${ }^{153}$ See, e.g., Zoltan Szente, Challenging the Basic Values - The Problems of the Rule of Law in Hungary and the Failure of the European Union to Tackle Them, in The Enforcement of EU LaW AND Values ENsuring Member States' Compliance 456 (Andras Jakab \& Dimitry Kochenov eds., 2017).

${ }^{154}$ Bień-Kacała, supra note 97 , at 428-43.

${ }^{155}$ Rosalind Dixon \& David Landau, Transnational constitutionalism and a limited doctrine of unconstitutional constitutional amendments, 13 INT'L J. CONST. L. 606, 629 (2015).

${ }^{156}$ Ryszard Balicki, Bezpośrednie stosowanie konstytucji [Direct application of a constitution], 4 KRAJOWA RADA SĄDOWNICTWA 13 (2016); Piotr Kardas \& Maciej Gutowski, Konstytucja z 1997 r. a model kontroli konstytucyjności prawa [1997 Constitution and a model of constitutional review], 4 PALESTRA 11 (2017).

${ }^{157}$ Leszek Garlicki, Sady a Konstytucja Rzeczypospolitej Polskie [Courts and the Constitution of the Republic of Poland] 7-8 PrZEgląD SĄDOWY 23 (2016); Leszek Garlicki \& Zofia A. Garlicka, External Review of Constitutional Amendments? International Law as a Norm of Reference, 44 IsR. L. REV. 343 (2011).

${ }^{158}$ The statement of the CT’s President Andrzej Rzepliński and unpublished judgment of Mar. 9, 2016, K 47/15. Koncewicz, supra note 29, at 31-33; Tomasz Tadeusz Koncewicz, On the Strategic Reading of the Constitutional Document. Mapping out Frontiers of New Constitutional Research, 2018 PRZEgląd Konstytucyjny 16 (2018).
} 
setting, this may be an ineffective measure. Moreover, taking over constitutional review should be itself viewed as potentially unconstitutional. Without a proper legal basis regarding the competence of the courts to assess constitutionality and to set aside unconstitutional legislation, this is unconstitutional, as it affects the rule of law and several of its components, such as legal certaintywhat the law is if a court sets aside only those laws it considers unconstitutional), the transparency of the legal system and state authorities, and predictability in the functioning of state organs. No "good will" aimed at overcoming unconstitutionality can make desperate measures constitutional. As the Hungarian CC stated in 1991 regarding the legal assessment of the transition, the rule of law cannot be built against the rule of law. At the same time, the idea of emergency judicial review could potentially be used by already captured courts to prevent retransformation.

Different solutions are offered in the scholarly literature. Menocal et al, when studying Latin American and African countries, hold that potential authoritarian top-down control should be replaced by effective checks and balances and accountability to citizens. ${ }^{159}$ In an illiberal democracy, however, everything is formally legal: There is an established and, to a certain extent, functioning mechanism of checks and balances, which may be effective in cases of no importance to the political decision-maker. The authors also fail to see, however, that checks and balances can only be effective to the extent that they actually shape the legal landscape so long as the political decision-maker complies. The same applies to accountability and mandatory voting, which are suggested by Pap and Śledzińska-Simon. ${ }^{160}$ Without substantive rules, which are to be adopted by those who would be their subjects, and compliance, this scheme would not be a reality. According to Diamond, economic development, globalization, and the information revolution may undermine all forms of authority and empower the citizens. ${ }^{161}$ Instead, in an illiberal democracy, the economy is also captured by members of the ruling party, and, because of neo-patrimonialism, an overturn is hardly imaginable. Therefore, economic development for "the others" seems to be a mere illusion. Populist nationalism as a whole is against economic globalization, tending to employ a protectionist economic policy to strengthen national companies, that is, the clientura. The information revolution may be the sole hope, but economic measures may also be applied to it, and information technology may be used for spreading populist nationalist ideas. Any retransformation would also require educated citizens. It is, however, quite a big challenge given the underfinanced and outdated educational policies that Hungary and Poland pursue. We might also note that Hungary has started to develop a nationalistic educational agenda instead of putting emphasis on liberal values. That is why developing a democratic culture that accommodates these values, as some authors suggest, ${ }^{162}$ seems to be a utopian ideal. Advocates of a substantial constitutional democracy seem to be left with the hope that civil society might organize itself to promote and safeguard the values of liberal democracy, and that it should do so in a legal and political environment which is far from friendly. This result, however, is highly doubtful.

The way out of this new regime of illiberalism, in a short or even mid-term, is apparently difficult. Precise societal, political, economic, and even psychological reasons, ${ }^{163}$ based on which the

\footnotetext{
${ }^{159}$ Menocal et al., supra note 6 , at 35 .

${ }^{160}$ András László Pap \& Anna Śledzińska-Simon, Mandatory Voting as a Tool to Combat the "New Populism", I-CONNECT BLOG (Apr. 19, 2017), iconnectblog.com/2017/04/mandatory-voting-and-the-new-populism/.

${ }^{161}$ Diamond, supra note 60 , at 153.

${ }^{162}$ E.g., Gábor Halmai, The decline of liberal democracy in Europe's midst, EuROzINE (Sept. 27, 2016), http://www.eurozine. com/the-decline-of-liberal-democracy-in-europes-midst/; Bugarić, supra note 6, at 241-44; Florin N. Fesnic, Can Civic Education Make a Difference for Democracy? Hungary and Poland Compared, 4 POL. STUD. 966 (2016).

${ }^{163}$ Blokker does not seem to have a legal understanding of the constitution; he perceives it as a "facilitatory device." Therefore, neither his point of departure, nor the offered solution meets the standards of our contextual and functional comparative approach. BLOKKER, supra note 6 , at 3, 6, 164, 166.
} 
capture of the constitution and constitutionalism might emerge, should be formatted and adequately addressed—probably by non-legal approaches— ${ }^{164}$ in the first instance.

\section{F. Conclusion}

In this Article, we have discussed what has happened in Hungary and Poland, and how these changes can be conceptualized in the field of comparative constitutional law. As a result, we have argued that Polish and Hungarian democratic degeneration shows unique and distinctive characteristics unlike those that have emerged in other countries ruled by populist politicians and experiencing democratic decay.

We have also made the case that Hungary and Poland, regardless of their differences, exemplify the distinct characteristics of an illiberal constitution. The case of Hungary and Poland is unique because, while each being Member States of the EU, they could transform their constitutional system to an extent that is almost incompatible with the values the EU stands for. They have been slowly sliding from their previous constitutional democracy status to authoritarianism, but they have not reached it yet. Quanitatively, according to different indexes, they are not in as bad shape as Turkey or Russia-the countries with which they are usually mentioned-but admittedly they are doing far worse than their European counterparts. Qualitatively, they have accommodated liberal constitutionalism for a while, unlike for instance Singapore or Venezuela-again, countries with which they are usually mentioned. There is a weak but tacitly existing constitutional constraint on the public power, which is the EU law, even though it has partly failed: Its defense mechanisms have not worked so far. The mere existence of EU law and its admittedly flawed implementation at the legislative level and the everyday application by adjudicative bodies may influence and prevent illiberal politicians from leading their countries into authoritarianism even faster. The use of the term of illiberal constitutionalism is intentional: It describes the Hungarian and Polish governmental systems between 2010-2019 and 2015-2019, respectively, and highlights the paradox these countries cause within the European Union.

Illiberal constitutionalism emerged through the populist capture of the constitutions and of constitutionalism. The capturing mechanism appears in the manner in which the constitutional changes are implemented, political and legal constitutionalisms are theorized, and the constitutional/national identity is interpreted. It is also present in the relativization of the rule of law and human rights and in the constitutionalization of populist nationalism, identity politics, patrimonialism, clientelism, and corruption. Each of these indicates that constitutional democracy exists only in a formal sense. Illiberal democracy is viewed as the functioning of a public power that upholds the main constitutional structure but lacks normative commitment to constraints on public power, and, consequently, where the main common, traditional constitutional values are relativized or only partially observed. In these states, each element of a liberal democracy, such as the rule of law, democracy, and human rights, is observable; not one is missing, but no element prevails in its entirety. There is no obvious lack of these constitutional elements, as stated by Kalypso Nicolaidis and Rachel Kleinfeld. ${ }^{165}$ Instead, there are flaws that may even be remedied, removed, or even smuggled back in. Nevertheless, Renáta Uitz correctly observes that a careful and informed analysis of the political, social, and historical context is needed when studying any constitutional texts. ${ }^{166}$ We may add that familiarization with constitutional jurisprudence and scholarly works,

\footnotetext{
${ }^{164}$ Narrative psychology may help. See Drinóczi \& Bień-Kacała, supra note 5; Fülöp et al., supra note 13; Murray, supra note 13 .

${ }^{165}$ Nicolaidis \& Kleinfeld hold that in illiberal democracies, one of the two elements of liberal democracies is missing. See Kalypso Nicolaidis \& Rachel Kleinfeld, Rethinking Europe's "Rule of Law" and Enlargement Agenda: The Fundamental Dilemma, 49 Sigma PAPERS 10, 11 (2012).

${ }^{166}$ Uitz, supra note 1 , at 299.
} 
and the better understanding of the psychological background and emotional characteristics of the particular society, may be also necessary for comprehending national legal changes and struggles.

As noted, illiberal democracy is shaped by slowly putting together the above-mentioned pieces of the puzzle; if the match is perfect, it will stand for a long time. Both Hungary and Poland display features of illiberal democracy, the reversal of which, in a short or even a mid-term, does not seem to be plausible. We have assumed that first societal, political, economic, and even psychological reasons of the emergence of illiberal political regime should be addressed by non-legal approaches, which can then be followed by discussion on adequate legal reforms. If this is the right methodology to address re-transformation, it leads us to two conclusions. First, once all these reasons have been revealed, we can address the issue of how, when, and by whom the re-transformation should be facilitated in the future. What is certain for now is that the applicable and earlier discussed exit strategies have proved to be insufficient; peaceful legal means are apparently useless to help re-transformation. Second, as law has its limitation as a social instrument, reforms built upon the non-legal experiences may be facilitated by legal means, but the law as an instrument cannot solve these problems alone.

Results of scientific narrative psychology and other social psychological empirical studies support our presumption that the emotional attitudes of the people and the community can be found behind the illiberal transformation and the failures of the public law mechanism. These stem from history and collective memory, and could likely be the result of the adaptation to the life circumstances imposed by the communist regime, which is prone to changing gradually over the course of time and in different, more liberal and democratic, circumstances. Regardless of the 20 or 25 years of liberal constitutionalism in Hungary and Poland, what we seem to have are-to possibly differing degrees: Lack of respect for others; compromised self-confidence; the feeling of being a victim, and all the attached sensations of inferiority; the need for a strong leader; prioritizing values of conservativism and hierarchy; and reluctance regarding or controversial attitudes towards the values of liberal constitutional democracy or open society, such as intellectual autonomy, individual liberty, and responsibility. All of these identity-related phenomena, which have apparently already been internalized, eventually combine to form a national and constitutional identity. This type of group identity, at certain historical moments, seemed and still seems to be fertile soil for populist leaders who have an illiberal vision of society and state. Nevertheless, it does not offer the best conditions for developing the civic virtues necessary for upholding a substantive constitutional democracy.

Cite this article: Drinóczi T, Bień-Kacała A (2019). Illiberal Constitutionalism: The Case of Hungary and Poland. German Law Journal 20, 1140-1166. https://doi.org/10.1017/glj.2019.83 